\title{
Facilitating an understanding of integrative physiology: emphasis on the composition of body fluid compartments
}

\author{
Mogamat Razeen Davids, Yeouda Edoute, Robert L. J ungas, \\ Surinder Cheema-Dhadli, and Mitchell L. Halperin
}

\begin{abstract}
As a teaching exercise, we used deductive reasoning and a quantitative analysis to convert a number of facts into a series of concepts to facilitate an understanding of integrative physiology and shed light on the composition of the different body fluid compartments. The starting point was the central need to regenerate ATP to perform biologic work. Because a large quantity of $\mathrm{O}_{2}$ must be delivered to cells at a sufficiently high concentration to aid its diffusion into mitochondria, approximately one third of the $\mathrm{O}_{2}$ in inspired air was extracted; this led to a $P_{\mathrm{CO}}$ in arterial blood of $40 \mathrm{mmHg}(1 \mathrm{mmHg}=133.322 \mathrm{~Pa})$. Blood flow to individual organs must be adjusted precisely to avoid having too low or too high a $P_{\mathrm{O}_{2}}$ in mitochondria - the latter augments the formation of reactive $\mathrm{O}_{2}$ species. The extracellular fluid (ECF) bicarbonate concentration $\left(E_{\mathrm{HCO}_{3}}\right)$ must be high to minimize $\mathrm{H}^{+}$buffering by proteins. This high $E_{\mathrm{HCO}_{3}}$ sets the ECF concentrations of ionized calcium $\left(\mathrm{Ca}^{2+}\right)$ and inorganic phosphate $\left(\mathrm{HPO}_{4}^{2-}\right)$ because of solubility issues. Three features defined the intracellular fluid (ICF) volume and composition. First, expelling monovalent anions minimized its mass (volume). Second, controlling the tissue $P_{\mathrm{CO}_{2}}$ ensured a relatively constant net valence on intracellular proteins. Third, the range of ICF Ca ${ }^{2+}$ concentrations must both induce regulatory signals and avoid $\mathrm{Ca}_{3}\left(\mathrm{PO}_{4}\right)_{2}$ formation. All the above were incorporated into the integrated response that optimized the capacity for vigorous exercise.
\end{abstract}

Key words: acid-base, bicarbonate, calcium, carbon dioxide, exercise, integrative physiology, intracellular fluid $\mathrm{pH}$, oxygen, water.

Résumé : Comme exercice pédagogique, nous avons utilisé le raisonnement déductif et une analyse quantitative pour convertir des faits en une série de concepts afin de faciliter la compréhension de la physiologie intégrative et de jeter une lumière sur la composition des différents compartiments des liquides corporels. Notre point de départ a été la nécessité de régénérer l'ATP pour effectuer un travail biologique. Étant donné qu'une grande quantité d'oxygène doit être distribuée aux cellules à une concentration suffisamment élevée pour faciliter sa diffusion dans les mitochondries, environ $1 / 3$ de l'oxygène de l'air inspiré a été extrait, ce qui a donné une $P_{\mathrm{CO}_{2}}$ dans le sang artériel de $40 \mathrm{~mm} \mathrm{Hg}$ $(1 \mathrm{mmHg}=133.322 \mathrm{~Pa})$. Le débit sanguin aux divers organes doit être ajusté de manière à équilibrer la quantité de $P_{\mathrm{O}_{2}}$ dans les mitochondries; une trop forte concentration favorise la formation des espèces réactives de l'oxygène. La concentration de bicarbonate extracellulaire (LEC) $\left(E_{\mathrm{HCO}_{3}}\right)$ doit être élevée pour atténuer le tamponnage des ions $\mathrm{H}^{+}$ par les protéines. Cette forte concentration de $E_{\mathrm{HCO}_{3}}$ règle les concentrations de calcium ionisé $\left(\mathrm{Ca}^{2+}\right)$ et de phosphate inorganique $\left(\mathrm{HPO}_{4}^{2-}\right)$ du LEC pour des raisons de solubilité. Trois caractéristiques ont défini la composition et le volume du liquide intracellulaire (LIC). Premièrement, l'expulsion des anions monovalents a diminué sa masse (volume). Deuxièmement, la régulation de la $P_{\mathrm{CO}_{2}}$ tissulaire a maintenu une valence nette relativement constante sur les protéines intracellulaires. Troisièmement, la plage de concentrations du $\mathrm{Ca}^{2+} \mathrm{du}$ LIC doit à la fois induire des signaux régulateurs et éviter la formation de $\mathrm{Ca}_{3}\left(\mathrm{PO}_{4}\right)_{2}$. Toutes ces données ont été incorporées dans la réponse intégrée qui a optimisé la capacité à effectuer un exercice vigoureux.

Received 7 March 2002. Published on the NRC Research Press Web site at http://cjpp.nrc.ca on 9 September 2002.

M.R. Davids. Nephrology Unit and Department of Internal Medicine, Stellenbosch University, Cape Town, South Africa.

Y. Edoute. Internal Medicine C, Rambam Medical Center, Faculty of Medicine, Technion Israel Institute of Technology, Haifa, Israel.

R.L. Jungas. Department of Physiology, University of Connecticut, Health Science Center, Farmington, CT 06030, U.S.A.

S. Cheema-Dhadli and M.L. Halperin. ${ }^{1,2}$ Division of Nephrology, St. Michael's Hospital, University of Toronto, Toronto, ON M5B 1A6, Canada.

${ }^{1}$ Corresponding author (e-mail: mitchell.halperin@utoronto.ca).

${ }^{2}$ Present address: St. Michael's Hospital Annex, University of Toronto, Laboratory 1, Research Wing, 38 Shuter Street, Toronto, ON M5B 1A6, Canada. 
Mots clés : acide-base, bicarbonate, calcium, dioxyde de carbone, exercice, physiologie intégrative, $\mathrm{pH}$ du liquide intracellulaire, oxygène, eau.

[Traduit par la Rédaction]

\section{Introduction}

Normal values for the volumes and concentrations of ions in the extracellular fluid (ECF) and intracellular fluid (ICF) compartments have been clearly defined. We ask: Why are these values the "normal" ones? With such a broad question, where should we begin? Which subject deserves more emphasis? How deeply should each subject be explored? Because of a need to be succinct, only selected subjects can be considered. The topics we shall focus on in a sequential fashion are energy metabolism, oxygen, carbon dioxide, acid-base, calcium, phosphate, water, cell voltage, and the integrative physiology of vigorous exercise. Because our aim is to focus on a breadth of ideas, no subject will be covered in depth and the literature will not be referenced in detail.

Each section begins with a broad yet simple question to focus attention on critical issues. We relied heavily on what we call a function/control analysis (Halperin and Rolleston 1993) - once the function becomes clear, one can deduce how that function is likely to be controlled. Subject matter quickly crosses traditional subspecialty boundaries and a quantitative analysis is an essential tool. The discussion of a particular line of inquiry leads ultimately to a crossroad. Only the path that is consistent with our objective of defining why we have the specific composition of the major body compartments will be followed.

\section{The central importance of energy}

This section begins with a consideration of work and energy. The correct amount of $\mathrm{O}_{2}$ must be delivered to tissues to permit the performance of biological work while not elevating the tissue concentration of $\mathrm{O}_{2}\left(P_{\mathrm{O}_{2}}\right)$ unduly. An obligatory link becomes evident between the $P_{\mathrm{O}_{2}}$ and the concentration of $\mathrm{CO}_{2}\left(P_{\mathrm{CO}_{2}}\right)$ in the blood and interstitial compartments. A list of the questions to be considered in this section is given in Table 1 .

\section{Question 1: What is the most important requirement for survival in an adult?}

\section{Define function}

While a supply of water, food, and $\mathrm{O}_{2}$ and the elimination of waste products are essential for survival, a source of energy for muscle contraction is needed for all. The ability to escape from danger (fight and flight response) and to perform other biological work such as ion pumping and biosynthesis all help to focus on the central importance of a source of energy. Adenosine triphosphate (ATP) is the body's energy currency and ensuring its continuous availability is the most important requirement for survival.

\section{Deduce controls}

Once the function is clear, its regulation can be deduced. Figure 1 is provided to illustrate where the metabolic process that leads to regeneration of ATP should be regulated. Because one cannot run faster simply because more food is consumed, the conclusion is obvious - performing work generates a signal (a rise in the concentration of adenosine diphosphate (ADP)) to stimulate energy metabolism and ATP regeneration. At this point, the emphasis switches to metabolic regulation in the setting of the physiology of vigorous exercise (the hunt for food).

\section{(a) Control of energy metabolism during vigorous exercise}

Question 2: Will the supply of $\mathrm{O}_{2}$ or fuel limit the rate of ATP formation during intense exercise?

\section{Define function}

A much more rapid rate of fuel oxidation and $\mathrm{O}_{2}$ consumption is needed to perform vigorous work.

\section{Deduce controls}

Both $\mathrm{O}_{2}$ and fuel are supplied ultimately from the blood. If their entry into cells were not the rate-limiting step, a quantitative analysis emphasizing the stoichiometry of fuel oxidation (eqs. $1 a$ and $1 b$ ) could help identify the likely limiting factor. To completely oxidize the $5 \mathrm{mmol}$ of glucose in $1 \mathrm{~L}$ of blood, $30 \mathrm{mmol}$ of $\mathrm{O}_{2}$ must be consumed $\left(6 \mathrm{O}_{2} / \mathrm{glu}-\right.$ cose, eq. $1 b$ ). Nevertheless, $1 \mathrm{~L}$ of blood contains only $8 \mathrm{mmol}$ of $\mathrm{O}_{2}$ (Appendix A). Therefore, the supply of $\mathrm{O}_{2}$ and (or) the accumulation of the product $\mathrm{CO}_{2}$ are the most likely factors that limit energy metabolism in steady state and thereby the capture of useable energy in the form of ATP. Of interest, much of the energy from fuel oxidation is released as heat in a relatively few nonequilibrium reactions. These irreversible reactions are the major sites where metabolic pathways are regulated.

$$
\begin{aligned}
& \text { Work }+ \text { ATP } \rightarrow \text { ADP }\left(+\mathrm{P}_{\mathrm{i}}\right) \\
& \begin{aligned}
& \text { Glucose }+6 \mathrm{O}_{2}+38 \text { ADP }+38 \mathrm{P}_{\mathrm{i}} \\
& \rightarrow 6 \mathrm{CO}_{2}+38 \text { ATP }+ \text { heat }
\end{aligned}
\end{aligned}
$$

where $\mathrm{P}_{\mathrm{i}}$ is inorganic phosphate.

\section{(b) The supply of $\mathrm{O}_{2}$}

$\mathrm{O}_{2}$ is now the central issue. Again, quantities and chemistry provide the basis to deduce answers to our questions. As background, the following facts help identify critical issues. Air is $21 \% \mathrm{O}_{2}$ and the balance is inert nitrogen gas; air has only trace amounts of the other important gas, $\mathrm{CO}_{2}$. Because atmospheric pressure is $760 \mathrm{mmHg}(1 \mathrm{mmHg}=133.322 \mathrm{~Pa})$ and water vapor pressure of fully humidified air at $37^{\circ} \mathrm{C}$ (body temperature) is $47 \mathrm{mmHg}$, air entering the lungs has a $P_{\mathrm{O}_{2}}$ of $21 \%(760-47 \mathrm{mmHg})$ or close to $150 \mathrm{mmHg}$ (Schmidt-Nielsen 1997). Since each millimole of $\mathrm{O}_{2}$ occupies $25.4 \mathrm{~mL}$ at body temperature, there is close to $8 \mathrm{mmol}$ $\mathrm{O}_{2} / \mathrm{L}$ inspired air at sea level. As we shall soon see, the percentage of $\mathrm{O}_{2}$ extracted from inspired air will dictate the ionic composition of the ECF compartment. 
Table 1. Questions concerning the importance of energy.

1. What is the most important requirement for survival in an adult?

2. Will the supply of $\mathrm{O}_{2}$ or fuel limit the rate of ATP formation during intense exercise?

3. What proportion of $\mathrm{O}_{2}$ should be extracted from each litre of inspired air?

4. What are the normal stimuli for ventilation?

5. What is the optimal relationship between the $P_{\mathrm{O}}$ and the binding of $\mathrm{O}_{2}$ to hemoglobin so that more $\mathrm{O}_{2}$ can be extracted from blood at a high $P_{\mathrm{O}_{2}}$ during exercise?

6. What should increase the blood flow rate to a specific organ?

7. Is there a danger if the mitochondrial $P_{\mathrm{O}}$, becomes too high?

8. What might the biological role of UCP-3 be in skeletal muscle during fasting?

Fig. 1. Function and control of metabolism. To perform work, ATP must be hydrolyzed (bottom arrow). Therefore, the central need of metabolism is to reconvert ADP to ATP (top arrow) at a rate to match the rate of use of ATP. Control of this process is initially by the rate of biological work. At higher rates of work, the supply of $\mathrm{O}_{2}$ becomes a rate-limiting step.

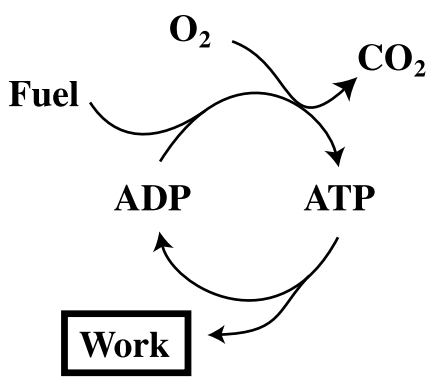

(c) Pulmonary extraction of $\mathrm{O}_{2}$

Question 3: What proportion of $\mathrm{O}_{2}$ should be extracted from each litre of inspired air?

\section{Define function}

Enough $\mathrm{O}_{2}$ should be extracted from inspired air to meet the metabolic demands of the body both at rest and during intense exercise.

\section{Deduce controls}

The circulatory system must deliver as much $\mathrm{O}_{2}$ as needed and at a sufficiently high $P_{\mathrm{O}_{2}}$ to optimize diffusion of $\mathrm{O}_{2}$ into mitochondria in steady state (Fig. 2). The fact that air is mainly nitrogen plays an important role in answering question 3. For example, if a person inspired $1 \mathrm{~L}$ of pure $\mathrm{O}_{2}$, and if one third of this $\mathrm{O}_{2}$ were extracted, the remaining gas would still have virtually the same $P_{\mathrm{O}_{2}}$, but its volume would now be two thirds of a litre. In contrast, when $\mathrm{O}_{2}$ is consumed from nitrogen-rich air, there is little change in total volume, so the $P_{\mathrm{O}}$ must decline appreciably. To select the optimum strategy for $\mathrm{O}_{2}$ extraction, three options will be considered.

(i) Extract most of the $\mathrm{O}_{2}$ in inspired air - While the work of breathing would be lower because a smaller volume of air needs to be inspired, the disadvantages are overwhelming. First, the $P_{\mathrm{O}_{2}}$ in alveolar air and arterial blood could become so low that rapid diffusion of $\mathrm{O}_{2}$ into mitochondria would be limited (Fig. 2). Second, there would be little reserve of $\mathrm{O}_{2}$ available in the lungs for immediate use during the fight or flight response. Third, the $P_{\mathrm{CO}_{2}}$ of alveolar air and body fluids would be very high - why this would be a fatal flaw
Fig. 2. Supply of $\mathrm{O}_{2}$. The rectangle represents a mitochondrion. Diffusion of $\mathrm{O}_{2}$ is needed, so a high $P_{\mathrm{O}_{2}}$ is required (site 1). For metabolism, the essential feature is the absolute quantity of $\mathrm{O}_{2}$ delivered to tissues (site 2). This is turn sets the requirement for a bound form of $\mathrm{O}_{2}$ (hemoglobin) with unique kinetics for $\mathrm{O}_{2}$ binding (see Fig. 3).

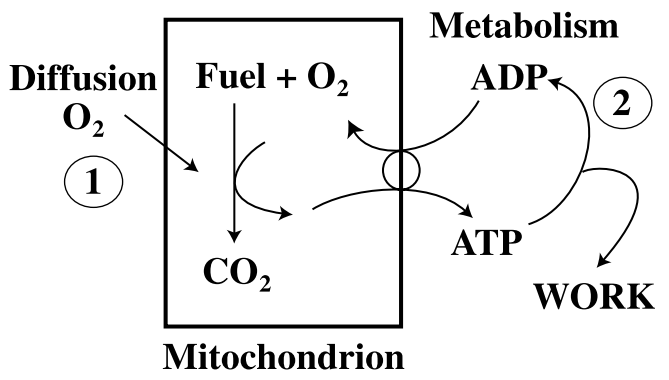

will be considered in more depth in Section II (control of the composition of the ECF compartment).

(ii) Extract only a tiny amount of $\mathrm{O}_{2}$ from each litre of inspired air - This strategy would result in both a high $P_{\mathrm{O}_{2}}$ and a maximum $\mathrm{O}_{2}$ reserve in alveolar air. The major disadvantage would be the very low $P_{\mathrm{CO}}$ in alveolar air and in blood; a minor disadvantage would be that the work of breathing would have to increase many fold.

(iii) Extract close to one third of the $\mathrm{O}_{2}$ from inspired air With this strategy, the $P_{\mathrm{O}_{2}}$ in the circulatory system can be high enough to support diffusion of $\mathrm{O}_{2}$ and it will set the $P_{\mathrm{CO}_{2}}$ in arterial blood and body fluids at close to $40 \mathrm{mmHg}$.

\section{(d) Control of ventilation}

\section{Question 4: What are the normal stimuli for ventilation?}

\section{Define function}

If $\mathrm{O}_{2}$ provided the stimulus for ventilation, the sensor could detect either the $\mathrm{O}_{2}$ content or the $P_{\mathrm{O}_{2}}$ of arterial blood.

\section{Deduce controls}

The $P_{\mathrm{O}_{2}}$ should become the major control of ventilation only when the content of $\mathrm{O}_{2}$ in arterial blood is clearly low. By examining Fig. 3, the $P_{\mathrm{O}_{2}}$ should stimulate ventilation when the arterial $P_{\mathrm{O}_{2}}$ has declined to the steep portion of the hemoglobin- $\mathrm{O}_{2}$ dissociation curve. This would not occur in everyday life, so other options will be explored. 
Fig. 3. Content and concentration of $\mathrm{O}_{2}$ in air. The quantity of $\mathrm{O}_{2}$ per litre of air is directly proportional to the $P_{\mathrm{O}_{2}}$ (top panel) whereas the quantity of $\mathrm{O}_{2}$ per litre of blood is a sigmoid function of the $P_{\mathrm{O}_{2}}$ (bottom panel). When tissues need more $\mathrm{O}_{2}$ at a high $P_{\mathrm{O}_{2}}$, this curve must shift to the right as illustrated by the vertical dashed line.
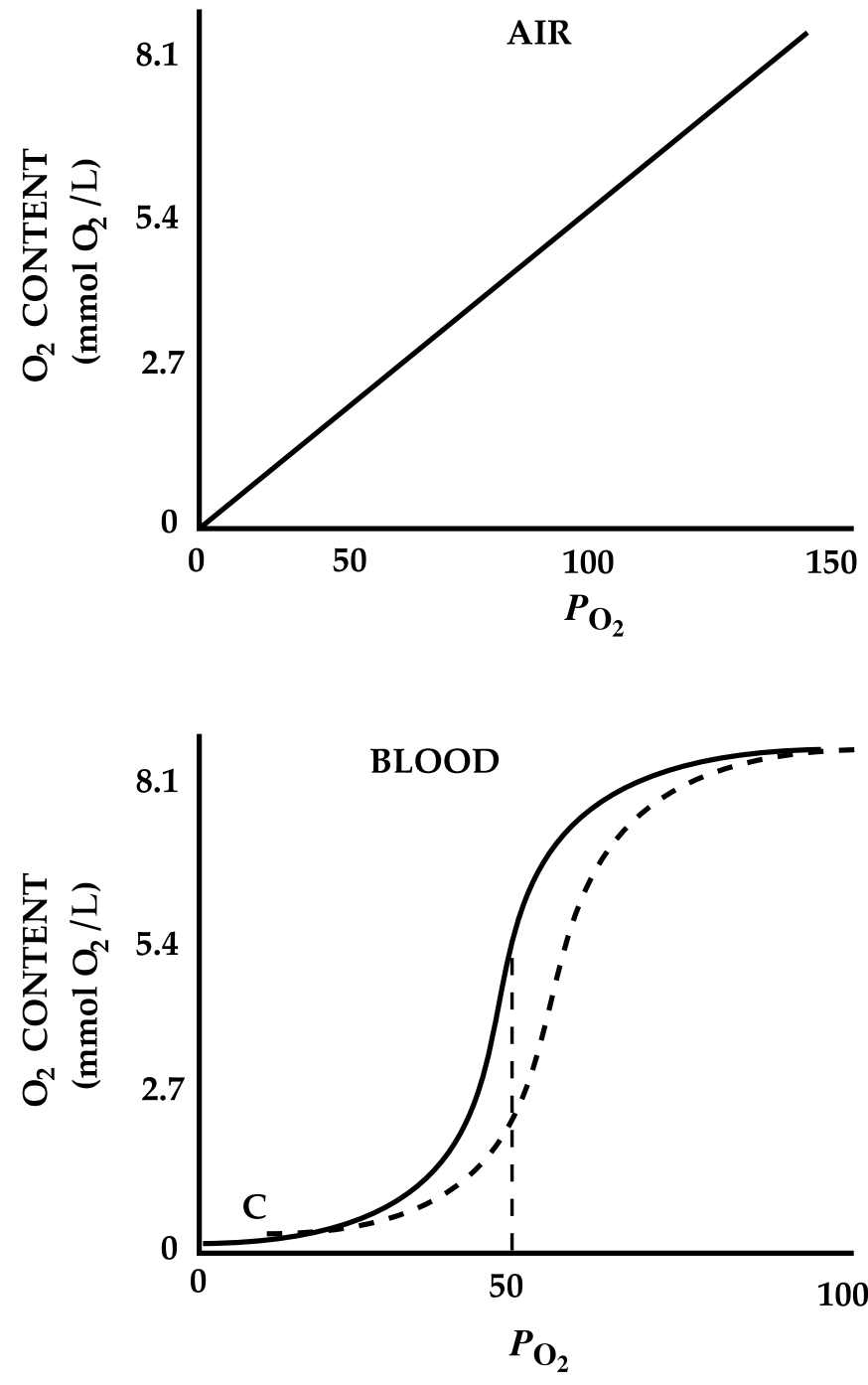

\section{Redefine function}

The consumption of $\mathrm{O}_{2}$ leads to the production of $\mathrm{CO}_{2}$ (eq. $1 b$ ). Hence, it is possible that $P_{\mathrm{CO}_{2}}$ could be the major signal to drive ventilation.

\section{Deduce controls}

Chemistry permits one to understand how ventilation may be controlled by $\mathrm{CO}_{2}$. First, $\mathrm{CO}_{2}$ is very soluble in water and it will be converted into carbonic acid $\left(\mathrm{H}_{2} \mathrm{CO}_{3}\right)$ (eq. 2). Although the speed of this reaction is not instantaneous, the reaction rate becomes very rapid because carbonic anhydrase (CA) is present. Second, $\mathrm{H}_{2} \mathrm{CO}_{3}$ dissociates very rapidly into $\mathrm{H}^{+}$and $\mathrm{HCO}_{3}^{-}$. The position of the equilibrium for the bicarbonate buffer system (BBS) is such that the ratio of the concentration of $\mathrm{HCO}_{3}^{-}\left(P_{\mathrm{HCO}_{3}}\right)$ to that of $\mathrm{H}^{+}$is close to 1 million to 1 in plasma. Since a small change in $P_{\mathrm{CO}_{2}}$ will generate one $\mathrm{H}^{+}$molecule and one $\mathrm{HCO}_{3}^{-}$molecule (eq. 2), it will induce a much larger percent change in the concentra- tion of $\mathrm{H}^{+}$than in that of $\mathrm{HCO}_{3}^{-}$. Accordingly, it is not surprising that the ultimate stimulus for ventilation might be $\mathrm{H}^{+}$ with or without a direct role for $P_{\mathrm{CO}_{2}}$. The compartment where this change in $\mathrm{H}^{+}$concentration is sensed will be one where there is the maximum change in $\mathrm{H}^{+}$concentration per rise in $P_{\mathrm{CO}_{2}}$ - i.e., CA is present with very few non- $\mathrm{HCO}_{3}^{-}$ buffers (proteins). Moreover, the metabolic production of $\mathrm{CO}_{2}$ and the blood flow rate to the site of regulation should not be variables that could control its $P_{\mathrm{CO}_{2}}$ and thereby ventilation. One site that meets these requirements is adjacent to the cerebrospinal fluid in the brain.

\section{(e) Delivery of $\mathrm{O}_{2}$ to tissues}

Because $\mathrm{O}_{2}$ is not very soluble in water and a large amount must be transported in blood, a bound form of $\mathrm{O}_{2}$ is needed (hemoglobin-bound $\mathrm{O}_{2}$ ) (Fig. 3). Hemoglobin must be able to donate the majority of its $\mathrm{O}_{2}$ to tissues at a high $P_{\mathrm{O}_{2}}$ to aid the diffusion process - this is especially important when the workload increases.

Question 5: What is the optimal relationship between the $\mathrm{P}_{\mathrm{O}_{2}}$ and the binding of $\mathrm{O}_{2}$ to hemoglobin so that more $\mathrm{O}_{2}$ can be extracted from blood at a high $\mathrm{P}_{\mathrm{O}_{2}}$ during exercise?

\section{Define function}

The release of virtually all of the $\mathrm{O}_{2}$ in blood at the tissue level must occur while its $P_{\mathrm{O}_{2}}$ is sufficiently high to permit adequate diffusion of $\mathrm{O}_{2}$ into mitochondria.

\section{Deduce controls}

To release $\mathrm{O}_{2}$ at a high $P_{\mathrm{O}_{2}}$, the kinetics of $\mathrm{O}_{2}$ binding to hemoglobin must be nonlinear (Fig. 3). Were this the only adaptation, the $\mathrm{O}_{2}$ delivery system would not be optimal. Therefore, modifiers that permit the downloading of $\mathrm{O}_{2}$ at a higher $P_{\mathrm{O}_{2}}$ should be present when work increases. The products of work, $\mathrm{CO}_{2}$ (Fig. 1) and heat, are two of the major causes of a rightward shift of this $\mathrm{O}_{2}$ content $-P_{\mathrm{O}_{2}}$ curve for hemoglobin (Fig. 3). Hydrogen ions are another modifier when not enough $\mathrm{O}_{2}$ is delivered to meet energy needs of an organ because, with a deficit of $\mathrm{O}_{2}$, ATP and $\mathrm{H}^{+}$are produced by anaerobic glycolysis. Moreover, a rise in $P_{\mathrm{CO}_{2}}$ also increases the $\mathrm{H}^{+}$concentration (eq. 2), so this $\mathrm{H}^{+}$signal is an important one. The BBS (eq. 2) will be considered in more detail when we discuss $\mathrm{H}^{+}$buffering in Section II.

$$
\mathrm{CO}_{2}+\mathrm{H}_{2} \mathrm{O} \underset{\mathrm{CA}}{\leftrightarrow} \mathrm{H}_{2} \mathrm{CO}_{3} \leftrightarrow \mathrm{H}^{+}+\mathrm{HCO}_{3}^{-}
$$

\section{( $f$ ) Adjusting the blood flow rate to individual organs}

\section{Question 6: What should increase the blood flow rate to} a specific organ?

\section{Define function}

The delivery of $\mathrm{O}_{2}$ to tissues is directly related to their blood flow rate. Both blood flow rate and metabolic rate should influence the $P_{\mathrm{O}_{2}}$ and $P_{\mathrm{CO}_{2}}$ in tissues.

\section{Deduce controls}

When an organ consumes more $\mathrm{O}_{2}$, signals are required to dilate its small arteries. Since $\mathrm{O}_{2}$ delivery is such an important function, one can anticipate redundant control mechanisms. 
Fig. 4. Uncoupling of oxidative phosphorylation. The horizontal structure represents the inner mitochondrial membrane. At the far left, the diffusion of $\mathrm{H}^{+}$into mitochondria drives ATP regeneration (coupled oxidative phosphorylation). In the central part of the figure, only complexes I and II are shown; they pump out $\mathrm{H}^{+}$and are linked by the diffusion of CoQ. Reduced CoQ will react with $\mathrm{O}_{2}$ to produce ROS. The UCP-3 is shown at the right. When ROS rise and fatty acids are present, flux of $\mathrm{H}^{+}$through UCP-3 rises and CoQ becomes less reduced but ATP is not regenerated.

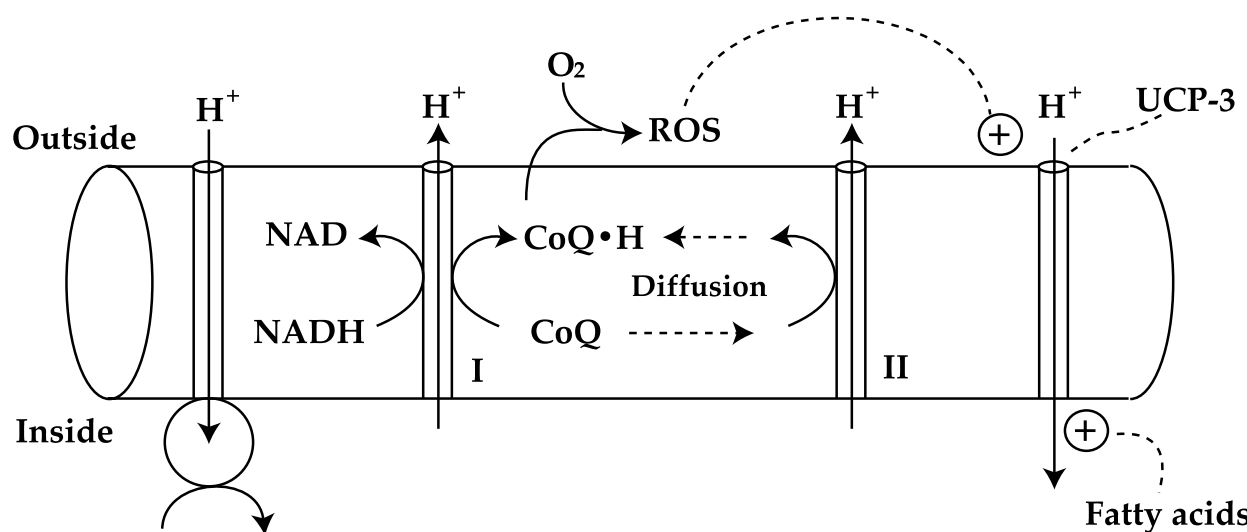

ADP ATP

Two major signals become obvious candidates for regulation of blood flow rate, a fall in $P_{\mathrm{O}_{2}}$ and a rise in $P_{\mathrm{CO}_{2}}$.

Individual organs have unique needs in terms of speed and sensitivity of response for regulation of their blood flow. The heart, for example, must augment its blood flow rate immediately when its work increases. Thus, the heart might be expected to have high local concentrations of vasodilators. At this point, an important measurement becomes relevant. The heart normally extracts $70 \%$ of its $\mathrm{O}_{2}$ delivery (Goodale et al. 1959). This ensures the needed low $P_{\mathrm{O}_{2}}$ and high $P_{\mathrm{CO}_{2}}$ to favor vasodilation. Moreover, a low local $P_{\mathrm{O}_{2}}$ could stimulate new blood vessel formation. There are other possible signals for control of blood flow. First, a link between a higher $P_{\mathrm{CO}_{2}}$ and insufficient $\mathrm{O}_{2}$ is a rise in the concentration of $\mathrm{H}^{+}$due to anaerobic glycolysis or possibly a product of ATP hydrolysis (called adenosine) (Lutz 1992). Therefore, a rise in concentration of $\mathrm{H}^{+}$and (or) adenosine are likely vasodilators. While these controls do operate, the need for additional and more sensitive ones will be illustrated in the response to the next question.

\section{Question 7: Is there a danger if the mitochondrial $\boldsymbol{P}_{\mathrm{O}_{2}}$ becomes too high?}

\section{Define function}

A lipid-soluble factor, coenzyme $\mathrm{Q}(\mathrm{CoQ})$, is a key component of the electron transport system that diffuses through the inner mitochodrial membrane when ATP is regenerated. CoQ links the first two complexes of the electron transport system (Fig. 4) (Mitchell 1961). The reduced form of CoQ will react with molecular $\mathrm{O}_{2}$ and form reactive oxygen species (ROS) (eq. 3). This is a nonenzymatic reaction, so it depends only on local concentrations of $\mathrm{O}_{2}$ and reduced CoQ (Beckman and Ames 1998). Therefore, if the $P_{\mathrm{O}_{2}}$ rises excessively near mitochondria, more ROS will be formed. The heart, for example, might be less likely to form ROS because is has a low interstitial $P_{\mathrm{O}_{2}}$ in vivo.

$$
\text { Reduced } \mathrm{CoQ}+\mathrm{O}_{2} \rightarrow \mathrm{O}_{2}^{-}(\mathrm{ROS})
$$

\section{Deduce controls}

Regulation of the concentration of ROS occurs by lowering their rate of formation or by increasing their rate of removal.

(i) Decrease the formation of ROS by lowering the $P_{\mathrm{O}_{2}}$ near mitochondria - Regulation of the $P_{\mathrm{O}_{2}}$ at the mitochondrial level requires that there be a system to match the blood flow rate to the rate of $\mathrm{O}_{2}$ consumption. During exercise, the blood flow rate to skeletal muscle must rise. The first step that permits this blood flow rise is the binding of adrenaline to one of its receptors in vascular smooth muscle cells. Vasodilatation is the response in skeletal muscle because $\beta$ receptors are the predominant ones in this organ. In contrast, in other organs, vasoconstriction is required, so $\alpha$-adrenergic receptors are their predominant receptors. Thus, blood can be diverted to supply skeletal muscle in high adrenergic states such as the flight or fight response - a necessary response because of the limited capacity to increase cardiac output. Nevertheless, this form of regulation lacks sensitivity because blood flow may have to increase immensely, but only to those muscles that are participating actively in the exercise. Hence, one can anticipate that local factors related to work load will be needed to adjust regional blood flow to individual skeletal muscles.

To understand how regional blood flow is regulated, the control of blood flow must be examined at a molecular level. Vasoconstriction requires that the concentration of $\mathrm{Ca}^{2+}$ in vascular smooth muscle cells must rise. Hence, one can anticipate that the ICF $\mathrm{Ca}^{2+}$ concentration $\left(I_{\mathrm{Ca}^{2+}}\right)$ will increase in these cells when vasoconstriction is the desired effect whereas this $I_{\mathrm{Ca}^{2+}}$ will fall when vasodilation is required (Fig. 5). To have a sustained rise in $I_{\mathrm{Ca}^{2+}}$ when an $\alpha$-adrenergic stimulus is present, voltage-gated $\mathrm{Ca}^{2+}$ channels in the plasma membrane of vascular smooth muscle cells must remain in an open configuration (for a review, see Landry and Oliver 2001). Regulation of the open-probability of these $\mathrm{Ca}^{2+}$ channels is via modulation of the magnitude of the negative voltage in these cells $-\mathrm{Ca}^{2+}$ channels will open in response to a less negative voltage and they will be closed when the intracellular voltage is more negative. 
Fig. 5. Vasoconstrictor tone in vascular smooth muscle cells. The circles represent a vascular smooth muscle cell. When the ICF has a less negative voltage because its $\mathrm{K}_{\mathrm{ATP}}$ and $\mathrm{K}_{\mathrm{Ca}}$ channels are closed, the voltage-gated $\mathrm{Ca}^{2+}$ channel can be maintained in an open configuration, permitting a sustained rise in the $I_{\mathrm{Ca}^{2+}}$. Hence, vasoconstriction will be the dominant response (left of the dashed line). In contrast, when $\mathrm{K}_{\mathrm{ATP}}$ channels are opened by $\mathrm{Mg} \cdot \mathrm{ADP}$, L-lactate anions $\left(\mathrm{L}^{-}\right)$, and $\mathrm{H}^{+}$or the $\mathrm{K}_{\mathrm{Ca}}$ channels are open secondary to an excessively high $I_{\mathrm{Ca}^{2+}}$, this leads to a more negative ICF voltage and closure of their voltage-gated $\mathrm{Ca}^{2+}$ channels. Nitric oxide (NO) causes both of these $\mathrm{K}^{+}$channels to be open and leads to vasodilation (right of the dashed line).

\section{VASOCONSTRICT}

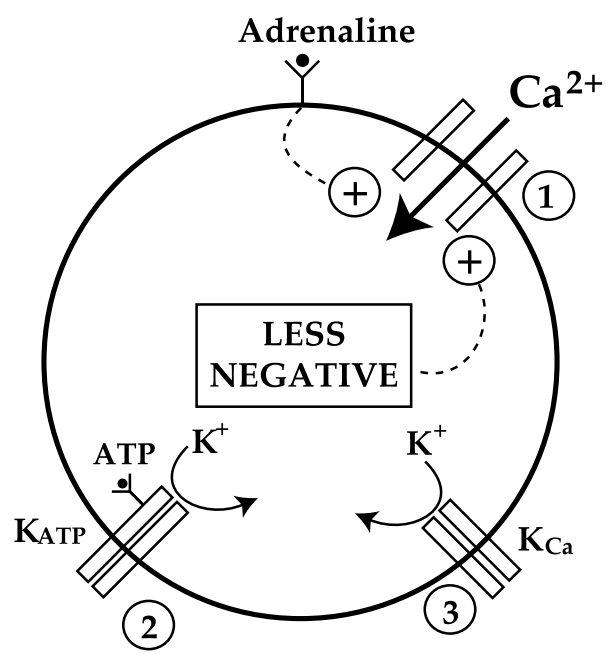

A negative intracellular voltage is created firstly by actions of $\mathrm{Na}^{+} / \mathrm{K}^{-}$ATPase because it pumps positive voltage out of cells - it exports three $\mathrm{Na}^{+}$in conjunction with the entry of two $\mathrm{K}^{+}$into cells (Russell 2000) — and secondly by $\mathrm{K}^{+}$diffusion out of cells down their concentration difference. This latter component requires that there be $\mathrm{K}^{+}$channels in the plasma membrane that are in an open configuration (Miller 2000). Hence, one could anticipate that factors that cause vasoconstriction close $\mathrm{K}^{+}$channels whereas stimuli for vasodilation will open $\mathrm{K}^{+}$channels and cause the more negative ICF voltage to reduce $\mathrm{Ca}^{2+}$ entry into cells.

There are two members of the $\mathrm{K}^{+}$channel family that participate in an important way in the regulation of negative voltage in vascular smooth muscle cells. First, there is the so-called ATP-gated $\mathrm{K}^{+}$channels $\left(\mathrm{K}_{\mathrm{ATP}}\right)$ - these $\mathrm{K}_{\mathrm{ATP}}$ channels would always be closed because the concentration of ATP is high enough in cells to permit constant binding to the $\mathrm{K}_{\mathrm{ATP}}$ cytoplasmic binding site (Quayle et al. 1997). Therefore, the regulatory unit of the $\mathrm{K}_{\mathrm{ATP}}$ channel must have a physiological regulatory site that binds monovalent ions such as Mg.ADP and L-lactate (Fig. 5). When vasodilation is needed, the $\mathrm{K}_{\mathrm{ATP}}$ channels should be open. The factors that open these $\mathrm{K}_{\mathrm{ATP}}$ channels and lead to a more negative ICF voltage become obvious from an analysis of the physiology of intense exercise (see Section IV). Anaerobic metabolism leads to the formation of ADP and L-lactic acid - the latter enters vascular smooth muscle cells via a monocarboxylic acid cotransporter (Juel and Halestrap 1999). Magnesiumbound $\mathrm{ADP}, \mathrm{H}^{+}$, and L-lactate anions act as ligands to open $\mathrm{K}_{\mathrm{ATP}}$ channels. As a result, the ICF voltage becomes more negative, voltage-gated $\mathrm{Ca}^{2+}$ channels close, and the $I_{\mathrm{Ca}^{2+}}$ concentration falls - this reduces vasoconstrictor tone and blood flow to working muscle rises as long as the exercise persists. This regulatory system is also important in $\beta$-cells of the pancreas, for example, but here the emphasis is on a
VASODILATE

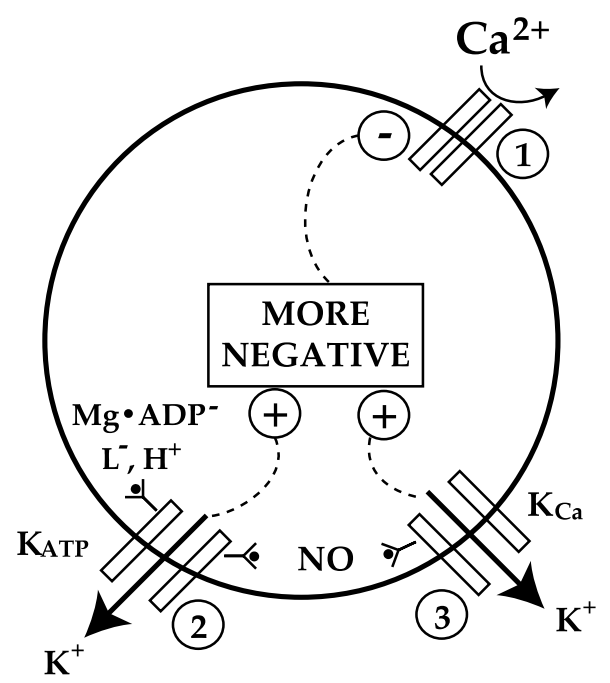

fall in ADP (Wollheim 2000). Glucose can stimulate the release of insulin by diminishing intracellular ADP levels, thereby closing $\beta$-cell $\mathrm{K}_{\mathrm{ATP}}$ channels, which lowers the intracellular negative voltage and results in more $\mathrm{Ca}^{2+}$ entry.

There must also be a redundancy of controls that control the $I_{\mathrm{Ca}^{2+}}$ because regulation of blood flow is needed in the absence of a rise in $\mathrm{H}^{+}$and L-lactate ${ }^{-}$. For example, there are other signal systems that operate to open $\mathrm{K}_{\mathrm{ATP}}$ channels in vascular smooth muscle cells - the best-known one is nitric oxide (Taylor and Geller 2000).

There is a second type of $\mathrm{K}^{+}$channel, a $\mathrm{Ca}^{2+}$-gated $\mathrm{K}^{+}$ channel $\left(\mathrm{K}_{\mathrm{Ca}}\right)$, that has a different function. These channels open when the $I_{\mathrm{Ca}^{2+}}$ rises to dangerously high levels - this limits the rise in the $I_{\mathrm{Ca}^{2+}}$ (see Section III for more discussion). These $\mathrm{K}_{\mathrm{Ca}}$ channels are also placed in a more open configuration by the vasodilator nitric oxide.

(ii) Decrease the quantity of ROS by increasing the removal of reduced $\operatorname{Co} Q-$ One can anticipate that there should be a system to remove ROS before they cause tissue damage. As background, the concentrations of the reduced forms of CoQ are usually high in mitochondria for two reasons. First, this allows mitochondria to regenerate ATP rapidly when ADP is formed as a result of performing biologic work. Second, high levels of reduced cofactors related to complex I of the electron transport system in mitochondria (NADH) are part of the essential components of the negative feedback signal system that inhibits key regulatory enzymes in energy metabolism (e.g., dehydrogenases in the Krebs cycle and of greatest importance, pyruvate dehydrogenase (Denton and Halestrap 1979; Randle 1986).

There are two ways to lower the level of reduced forms of CoQ if the level of ROS were to rise. First, the tight linkage between mitochondrial $\mathrm{O}_{2}$ consumption and the availability of ADP can be uncoupled (Mitchell 1961). This uncoupling of oxidative phosphorylation is achieved by permitting $\mathrm{H}^{+}$to 
Fig. 6. Role of tissue $P_{\mathrm{CO}_{2}}$ in the selection of intracellular buffer systems. The aim of buffering is to prevent $\mathrm{H}^{+}$from binding to proteins in cells; this can occur if the tissue $P_{\mathrm{CO}_{2}}$ falls. For this to happen, the arterial $P_{\mathrm{CO}_{2}}$ must fall due to stimulation of ventilation. There must also be a fall in the venous $P_{\mathrm{CO}_{2}}$. The latter will be present if the blood flow rate rises. When the tissue $P_{\mathrm{CO}_{2}}$ falls, the $\mathrm{H}^{+}$ concentration in cells will fall so intracellular proteins $\left(\mathrm{H} \cdot \mathrm{PTN}^{+}\right)$will not buffer $\mathrm{H}^{+}$; rather, $\mathrm{H}^{+}$will be removed solely by the $\mathrm{BBS}$.

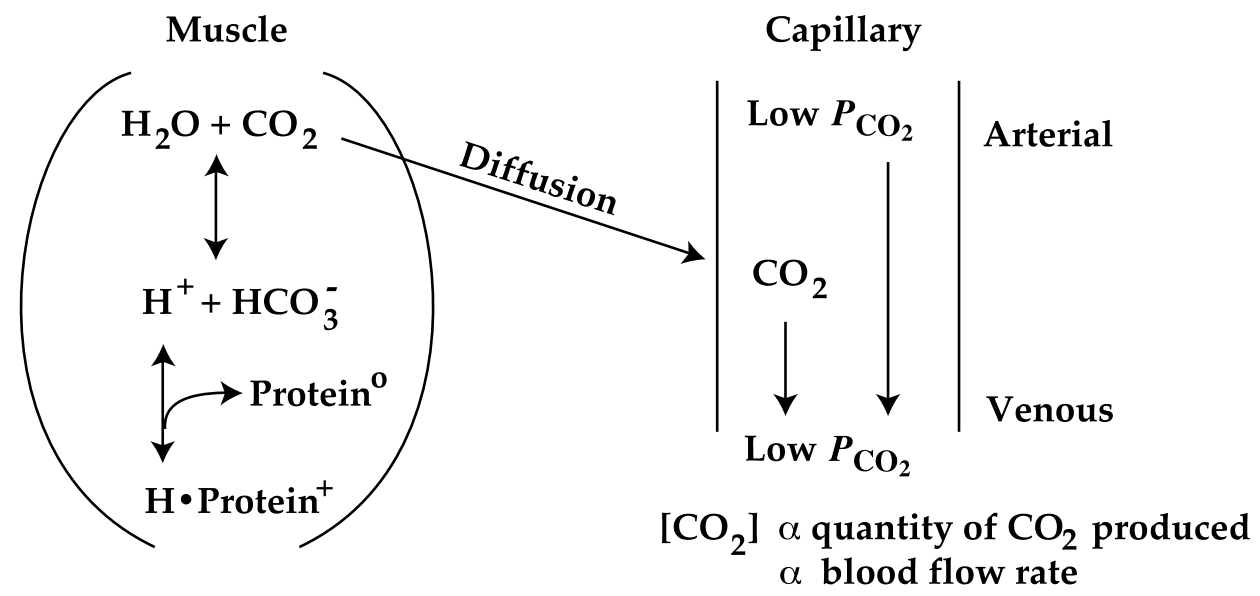

enter mitochondria by a pathway distinct from their usual entry pathway that regenerates ATP (Fig. 4). This alternate $\mathrm{H}^{+}$entry pathway is catalyzed by proteins called uncoupler proteins (UCP) (Lowell and Spiegelman 2000) that are activated by an increased concentration of ROS. Therefore, with a faster flux through the electron transport system, both the local $P_{\mathrm{O}_{2}}$ and the level of ROS decline, lowering ROS formation (eq. 3). Second, ROS can be removed by catabolism catalyzed by superoxide dismutase (SOD and catalase). In fact, when mitochondria are incubated in the presence of $\mathrm{SOD}, \mathrm{O}_{2}^{-}$levels decline and this inhibits uncoupled respiration because of a decreased flux through UCP-3 (Echtay and Brand 2001).

\section{Question 8: What might the biological role of $\mathrm{UCP}-3$ be in skeletal muscle during fasting?}

A puzzling feature of a member of the UCP family, UCP3 in skeletal muscle, is that it is induced by 5 - to 10 -fold during starvation (Boss et al. 1997). Hence, energy appears to be wasted when it is most needed.

\section{Define function}

It is clear that thermogenesis and wasting of energy stores are not the primary function of UCP-3 in skeletal muscle. Some claim that UCP provides advantages for metabolic regulation. An alternative speculation is that UCP-3 provides a means to lower the concentration of ROS (Brand 2000; Harper et al. 2001).

\section{Deduce controls}

If the rate of mitochondrial respiration were to increase, the steady-state concentration of the reduced forms of CoQ would decline (eq. 3). Hence, inducing UCP-3 in starvation could keep the level of ROS from rising excessively when flux through the electron transport system is low. This uncoupled flux of $\mathrm{H}^{+}$into mitochondria via UCP-3 will cause an energy drain, so the control system should be extended to consider which fuel should be oxidized. There are limited stores of carbohydrate and the levels of ketoacids must be maintained because they are the primary fuel for the brain in prolonged starvation (Owen et al. 1967). Therefore, the obvious fuel to oxidize in skeletal muscle for its uncoupled ox- idation is fatty acids. In fact, ROS stimulate UCP-3 flux if fatty acids are available (Rial et al. 1983).

In summary, the feedback loop is complete because the reduced forms of $\mathrm{CoQ}$ activate $\mathrm{UCP}-3$ in skeletal muscle. Flux through UCP-3 lowers the reduced forms of CoQ levels and a new steady state is produced. This system requires a high level of fatty acids so oxidation of protein (potential glucose) can be inhibited, thereby conserving lean body mass - the price to pay is a small increase in the catabolism of stored triglycerides. As we shall see when intense exercise is discussed (Section V), when exercise stops, there will be a period when blood flow to working muscles is high, yet demand for $\mathrm{O}_{2}$ is now much less. At this time, there will be a high $P_{\mathrm{O}_{2}}$ and a high concentration of the reduced forms of CoQ. Therefore, if UCP-3 flux rose, less ROS would be formed.

\section{Composition of the ECF compartment}

The composition of the ECF compartment will be dictated by the fact that its $P_{\mathrm{CO}_{2}}$ is close to $40 \mathrm{mmHg}$. Although a number of facts suggest that the concentration of $\mathrm{H}^{+}$should be regulated as a primary process, an argument will be put forward that it may be more important to control the ECF concentration of $\mathrm{HCO}_{3}^{-}\left(E_{\mathrm{HCO}_{3}}\right)$. Two facts then act in concert to select the optimal $E_{\mathrm{HCO}_{3}}$, a high value to buffer $\mathrm{H}^{+}$in a sprint, yet not too high to maintain an optimal ECF $\mathrm{Ca}^{2+}$ concentration $\left(E_{\mathrm{Ca}^{2+}}\right)$. This optimal $E_{\mathrm{HCO}_{3}}$ should set the $E_{\mathrm{Ca}^{2+}}$ and divalent inorganic phosphate ( $\left.\mathrm{HPO}_{4}^{2-}\right)$ concentrations so that they would be virtually equal and that their ion product would be very close to the solubility product constant $\left(K_{\mathrm{sp}}\right)$ of $\mathrm{Ca}_{3}\left(\mathrm{PO}_{4}\right)_{2}$. The questions to be addressed in this section are summarized in Table 2.

\section{(a) $\mathrm{CO}_{2}$ and buffering of $\mathrm{H}^{+}$}

There are two ways to think about $\mathrm{H}^{+}$buffering. First, the traditional view is that buffering can be thought of as simply a means to prevent a large rise in the $\mathrm{H}^{+}$concentration in the body. From a slightly different perspective, the function of the BBS is to remove $\mathrm{H}^{+}$without permitting a significant rise in the $\mathrm{H}^{+}$concentration. $\mathrm{CO}_{2}$ is central to the control of 
Table 2. Questions concerning the ECF compartment.

9. Is buffering of $\mathrm{H}^{+}$always a beneficial process in physiology?

10. Which ion, $\mathrm{H}^{+}$or $\mathrm{HCO}_{3}^{-}$should dictate the concentration of the other one?

11. Why might $\mathrm{Ca}^{2+}$ salts precipitate in only some regions of the ECF compartment?

the $\mathrm{H}^{+}$concentration (eq. 2; Fig. 6). To remove a big $\mathrm{H}^{+}$ load, there must be a very large amount of $\mathrm{HCO}_{3}^{-}$and this $\mathrm{HCO}_{3}^{-}$must in some way have a high likelihood of binding $\mathrm{H}^{+}$at their concentration in body fluid compartments.

\section{Question 9: Is buffering of $\mathrm{H}^{+}$always a beneficial process in physiology?}

\section{Define function}

If the $\mathrm{H}^{+}$concentration were to rise, $\mathrm{H}^{+}$would bind to all $\mathrm{H}^{+}$acceptors including proteins in cells. When $\mathrm{H}^{+}$bind to proteins, their charge, shape, and possibly their function will be altered (eq. 4).

\section{[4] $\quad \mathrm{H}^{+}+\operatorname{protein}^{0} \leftrightarrow \mathrm{H} \cdot$ protein $^{+}$}

\section{Deduce controls}

Because our major enzymes, transporters, and contractile elements are proteins, only few $\mathrm{H}^{+}$should bind to them. Nevertheless, if the $\mathrm{H}^{+}$concentration were to rise, simple chemistry mandates that $\mathrm{H}^{+}$would bind to proteins. This dichotomy of removing a $\mathrm{H}^{+}$load while preserving protein structure can be resolved by having a unique system that will remove $\mathrm{H}^{+}$before the $\mathrm{H}^{+}$concentration rises, forcing $\mathrm{H}^{+}$ to bind to $E_{\mathrm{HCO}_{3}}$ (Fig. 6). The mechanism becomes obvious when $\mathrm{CO}_{2}$ is the focus of attention. Reducing the $\mathrm{CO}_{2}$ concentration will drive eq. 2 to the left. While this lowers both the $\mathrm{HCO}_{3}^{-}$and $\mathrm{H}^{+}$concentrations, the effect on the $\mathrm{H}^{+}$concentration is relatively much larger because the $E_{\mathrm{HCO}_{3}}$ is almost $10^{6}$-fold larger than that of $\mathrm{H}^{+}$.

\section{Question 10: Which ion, $\mathrm{H}^{+}$or $\mathrm{HCO}_{3}^{-}$, should dictate the concentration of the other one?}

Because the arterial $P_{\mathrm{CO}_{2}}$ was fixed by the amount of $\mathrm{O}_{2}$ extracted from each litre of inspired air, the body can "choose" to have a given concentration of $\mathrm{H}^{+}$or $\mathrm{HCO}_{3}^{-}$. Once one is selected, the other becomes the dependent variable (eq. 2). Although one could mount an argument for regulating the concentration of either $\mathrm{H}^{+}$or $\mathrm{HCO}_{3}^{-}$, a compelling reason to choose one versus the other is elusive. Therefore, we shall seek a specific property of $\mathrm{H}^{+}$or $\mathrm{HCO}_{3}^{-}$ that could help with this decision.

\section{(b) Regulate the $\mathrm{H}^{+}$or the $\mathrm{HCO}_{3}^{-}$concentration}

(i) The body should regulate the concentration of $\mathrm{H}^{+}-$ Let us begin with a bias: $\mathrm{H}^{+}$are much more important than $\mathrm{HCO}_{3}^{-}$because they may bind to proteins changing their charge, shape, and possibly their function (eq. 4). The next step is to select the most common acid that accumulates in a large amount in physiologic settings, L-lactic acid (Cohen and Woods 1976) (See Appendix C). Consider cardiogenic shock where L-lactic acid accumulates due to accelerated anaerobic glycolysis secondary to poor delivery of $\mathrm{O}_{2}$ to tissues. Analysis of data from these patients provides a statistical association for the primacy of $\mathrm{H}^{+}$(i.e., the higher the $\mathrm{H}^{+}$concentration, the higher the mortality); however, all that was established was an association, not a causal rela- tionship. Other data could be cited to support the view that $\mathrm{H}^{+}$are more important than $\mathrm{HCO}_{3}^{-}$. Studies performed in vitro indicate that when the $\mathrm{H}^{+}$concentration rises, less adrenaline binds to its receptors in the heart (Nahas et al. 1967). The heart rate and the strength of contraction decline when there is less adrenergic activity.

It is important to recognize that one never proves that a hypothesis is correct (Beveridge 1951). Rather, if one fails to disprove it, that hypothesis maintains its credibility. Therefore, it is important to seek a "flawless" experiment to disprove the hypothesis concerning the primacy of $\mathrm{H}^{+}$. The most common physiological basis for L-lactic acidosis is a sprint (Cheetham et al. 1986). In fact, after $10 \mathrm{~s}$, the L-lactic acidosis may be more severe than during cardiac arrest, but the sprinter survives and has an excellent cardiac output. Therefore, it is difficult to attribute the poor cardiac output simply to a rise in $\mathrm{H}^{+}$and (or) L-lactate anion concentrations. Moreover, failure to deliver $\mathrm{O}_{2}$ at an adequate rate for ATP regeneration might explain the mortality in cardiac arrest and the accumulation of L-lactic acid could be a secondary event. Alternatively, the high $P_{\mathrm{CO}_{2}}$ in tissues due to a very slow blood flow rate could have led to diminished buffering of $\mathrm{H}^{+}$by the BBS and more $\mathrm{H}^{+}$binding to proteins (Fig. 6). Therefore, the primary importance of $\mathrm{H}^{+}$was not established.

(ii) The body should regulate the concentration of $\mathrm{HCO}_{3}^{-}-$ The $E_{\mathrm{HCO}_{3}}$ should be as high as possible to permit the maximum number of $\mathrm{H}^{+}$to be eliminated by the BBS during a sprint. Nevertheless, there is an upper limit for this $E_{\mathrm{HCO}_{3}}$ because $\mathrm{HCO}_{3}^{-}$is involved in another reaction, its conversion to carbonate ions (eq. 5). The carbonate so-formed could react with ionized $\mathrm{Ca}^{2+}$ forming insoluble calcium carbonate $\left(\mathrm{CaCO}_{3}\right)$ (eq. 6). The requirement for an ionized $E_{\mathrm{Ca}^{2+}}$ that is close to $1 \mathrm{mmol} / \mathrm{L}$ will be discussed in the next section. Independent forms of regulation of the $E_{\mathrm{HCO}_{3}}$ (plus carbonate) and $E_{\mathrm{Ca}^{2}+}$ can be anticipated.

$$
\begin{aligned}
& \mathrm{HCO}_{3}^{-} \leftrightarrow \mathrm{H}^{+}+\mathrm{CO}_{3}^{2-} \\
& \mathrm{Ca}^{2+}+\mathrm{CO}_{3}^{2-} \rightarrow \mathrm{CaCO}_{3} \downarrow
\end{aligned}
$$

\section{(c) Integrative physiology of calcium}

Question 11: Why might $\mathrm{Ca}^{2+}$ salts precipitate in only some regions of the ECF compartment?

$\mathrm{Ca}^{2+}$ salts that form a precipitate provide the rigid structure of bone. Bone formation demands that the substrates in eqs. 6 and 7 be close to their $K_{\mathrm{sp}}$. Because bone formation is important for growth, the product of the concentrations of carbonate and $\mathrm{Ca}^{2+}$ as well as $\mathrm{HPO}_{4}^{2-}$ and $\mathrm{Ca}^{2+}$ should be close to their respective $K_{\mathrm{sp}}$. Moreover, it should not be a surprise that the plasma $\mathrm{HPO}_{4}^{2-}$ concentration is higher in children because $\mathrm{Ca}_{3}\left(\mathrm{PO}_{4}\right)_{2}$ is the major form of $\mathrm{Ca}$ precipitate in bone and bone accretion occurs in children. Because it would be very disadvantageous to form $\mathrm{Ca}^{2+}$ precipitates in soft tissues, other factors in addition to the $K_{\mathrm{sp}}$ for $\mathrm{Ca}^{2+}$ 
Table 3. Questions concerning the ICF compartment.

12. What accounts for the majority of body mass?

13. What features would be needed to keep anions or cations outside cells?

14. Why is the ICF volume so large ( $40 \%$ of body mass)?

15. What would be needed to prevent the negative voltage in cells from expelling $\mathrm{HCO}_{3}^{-}$from cells?

16. What is the consequence of raising the concentration of $\mathrm{HPO}_{4}^{2-}$ in the ICF compartment during intense exercise?

17. In thermodynamic terms, how many fold must the $I_{\mathrm{Ca}^{2+}}$ rise so that after binding to its receptor on a regulatory signal protein, there will be enough energy to induce the desired protein conformational change?

Fig. 7. Minimizing the volume of water in the body. The circles represent the size of the ICF compartment. The osmolalities of the ECF and ICF are equal because cell membranes are permeable to water. The volume of the ICF compartment will be twice as large if it contains an equal number of monovalent cations $\left(\mathrm{K}^{+}\right)$and anions $\left(\mathrm{Cl}^{-}\right)$, as shown in the left portion of the figure. In contrast, if the electrical force (negative voltage) expels monovalent $\mathrm{Cl}^{-}$through ion-specific $\mathrm{Cl}^{-}$channels and the ICF has polyvalent macromolecular phosphate anions for electroneutrality, the volume of the ICF compartment will halve at the same total osmolality (right portion of the figure).

All anions are monovalent

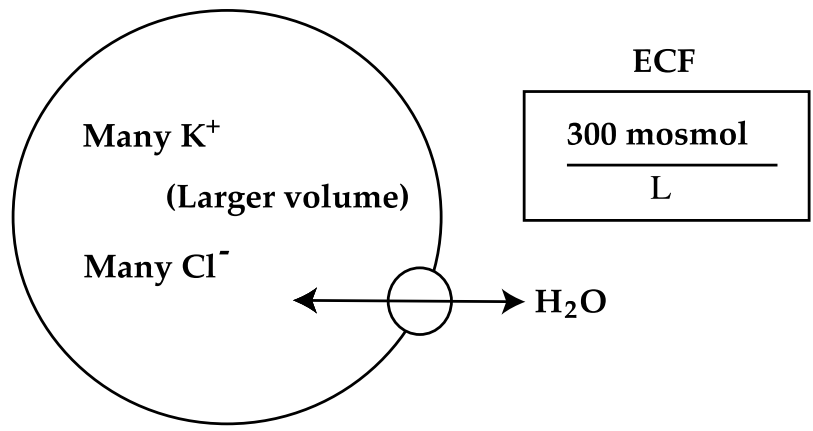

All anions are polyvalent

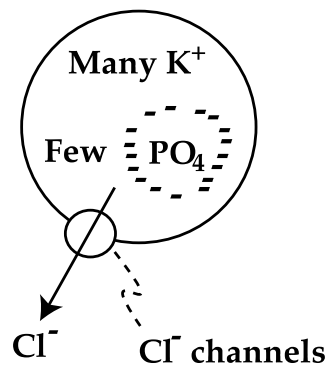

salts must be considered. Precipitation reactions can be favored or retarded depending on the presence of stimulators or inhibitors of precipitation. Therefore, one can anticipate that the chemistry of $\mathrm{Ca}^{2+}$ and $\mathrm{HPO}_{4}^{2-}$ will permit supersaturated solutions and that a compound that initiates precipitation from a supersaturated solution is ideal in bone but could be harmful elsewhere.

$$
3 \mathrm{Ca}^{2+}+2 \mathrm{HPO}_{4}^{2-} \rightarrow \mathrm{Ca}_{3}\left(\mathrm{PO}_{4}\right)_{2} \downarrow
$$

\section{(d) Selection of the optimal ionized $\mathrm{Ca}^{2+}$ concentration}

When eq. 7 is examined, one should consider both the $K_{\text {sp }}$ and the ratio of $\mathrm{Ca}^{2+}$ to $\mathrm{HPO}_{4}^{2-}$ in the $\mathrm{Ca}_{3}\left(\mathrm{PO}_{4}\right)_{2}$ precipitate. Therefore, the appropriate $E_{\mathrm{HCO}_{3}}$ to select should depend both on buffering of $\mathrm{H}^{+}$(high $E_{\mathrm{HCO}_{3}}$ ) and in selecting an $E_{\mathrm{Ca}^{2+}}$ that results in near-equal concentration of ionized $\mathrm{Ca}^{2+}$ and $\mathrm{HPO}_{4}^{2-}$ in the ECF compartment for more efficient mineralization of bone.

\section{Intracellular fluid compartment}

The ICF compartment is the largest one in the body; it contains our vital enzyme systems. Precipitation of $\mathrm{Ca}^{2+}$ should never occur in cells. The key issues for the ICF are to limit its size (mass) and to provide an optimal environment that permits $I_{\mathrm{Ca}^{2+}}$ to be a metabolic regulator. The questions to be addressed in this section are summarized in Table 3. (a) Efficiency of movement: the need to minimize body mass

Question 12: What accounts for the majority of body mass?

\section{Define function}

Should a subject have a smaller mass, less energy need be expended during intense exercise. To decrease mass, the quantity of the major constituent of the body, water, must be as small as possible. The number of particles dissolved in water determines body water content because there is a constant effective osmolality of body fluids. The upper limit on the effective osmolatity is one that prevents the effects of a high ionic strength on protein structure.

\section{Deduce controls}

To understand how a minimum water content can be achieved, the concept of osmolality in body fluid compartments becomes paramount (Fig. 7). There are two components that dictate how much water exists in cells: the total osmotic pressure and the number of dissolved solute molecules in the ICF compartment.

\section{Question 13: What features would be needed to keep anions or cations outside cells?}

\section{Define function}

To have less body water, one needs a smaller number of solute molecules and (or) a high value for osmolality of body fluids.

\section{Deduce controls}

Applying these concepts to the largest water compartment (ICF), the majority of ICF osmoles are ions. The number of 
positively and negatively charged ions must be virtually equal in all body compartments (very tiny differences actually occur to induce an electrical force (Giebisch 1998)). A smaller number of molecules would be present in cells if many of its ions were present as polyvalent macromolecules instead of monovalent ions. In fact, the majority of anions in the ICF compartment are polyvalent organic phosphate anions (Halperin and Jungas 1983). To maintain a low quantity of monovalent anions in cells, there must be a force to export them from cells (negative voltage in the ICF) along with open ion channels that permit them to exit from cells (Fig. 7). This negative voltage must be large enough to expel most of these monovalent anions, i.e., be greater than $-60 \mathrm{mV}$ (create a 10-fold concentration difference). Because the most abundant monovalent anion is $\mathrm{Cl}^{-}$, cell membranes should (and do) have specific $\mathrm{Cl}^{-}$channels (Jentsch 2000).

A quantitative analysis emphasizes the importance of ensuring that there are few monovalent anions in the ICF compartment. Water accounts for two thirds of body mass $(45 \mathrm{~L}$ or $45 \mathrm{~kg}$ in a $70-\mathrm{kg}$ adult) and two thirds of this water is in cells $(30 \mathrm{~L}$ or $30 \mathrm{~kg}$ ) because of the large number of ICF osmoles that are predominantly $\mathrm{K}^{+}$. If ICF anions were all monovalent, the number of osmoles in the ICF compartment would also double (Fig. 7). Hence, at the same osmolality, the ICF volume would double. Therefore, if $\mathrm{Cl}^{-}$remained in the ICF compartment, body mass in a $70-\mathrm{kg}$ adult would rise by close to $30 \mathrm{~kg}$ ! To complete this thought process, a negative voltage in the ICF is needed to expel $\mathrm{Cl}^{-}$.

\section{Question 14: Why is the ICF volume so large (40\% of body mass)?}

\section{Define function}

The number of solute molecules at a given effective osmolality determines the volume of the ICF compartment.

\section{Deduce controls}

The vast majority of ICF solutes are $\mathrm{K}^{+}$and their number is determined by the number of macromolecular anions because of the requirement for electroneutrality. Because of biological complexity, a large amount of the nuclear macromolecule DNA is needed (Alberts et al. 1989). Organic phosphate is a major constituent of DNA. Another nucleic acid, RNA, is needed for the dynamic process of protein synthesis, and phospholipids serve many functions. Part of the economy of volume is achieved by having these organic phosphates in a monovalent, diester form. Therefore, the need for organic phosphates dictates the ICF $\mathrm{K}^{+}$content (electroneutrality) and thereby the ICF volume.

It is also reasonable to ask why the major cations in the ICF compartment are not divalent because this would decrease the number of effective solutes in the ICF compartment. This would be a poor strategy because divalent cations such as $\mathrm{Ca}^{2+}$ and $\mathrm{Mg}^{2+}$ would form precipitates with $\mathrm{HPO}_{4}^{2-}$ if their concentrations exceeded a few millimoles per litre.

To have the smallest mass, most of our stored energy should be insoluble in water (fat). Nevertheless, this solution creates problems for the transport of energy as fat in an aqueous environment, but this topic will not be developed in this article.

\section{(b) Control of the $\mathrm{H}^{+}$concentration in the ICF compartment}

Since our vital enzymes and transporters are proteins, their structure must be maintained. This in turn demands a specific $\mathrm{H}^{+}$concentration in the ICF compartment to minimize $\mathrm{H}^{+}$binding to proteins (eq. 4). Since $\mathrm{O}_{2}$ consumption and the need for a high $P_{\mathrm{O}_{2}}$ fix the $P_{\mathrm{CO}_{2}}$, one could have a near-constant $\mathrm{H}^{+}$concentration by regulating the concentration of $\mathrm{H}^{+}$or $\mathrm{HCO}_{3}^{-}$in the ICF compartment (eq. 2). It is also advantageous to have a relatively high amount of $\mathrm{HCO}_{3}^{-}$ available for buffering of $\mathrm{H}^{+}$inside cells. If, as with $\mathrm{Cl}^{-}$, the negative voltage in cells were able to expel $\mathrm{HCO}_{3}^{-}$from or attract $\mathrm{H}^{+}$into cells, we could not have an adequate amount of $\mathrm{HCO}_{3}^{-}$inside cells for "good" buffering (protecting the electrical charge on proteins).

\section{Question 15: What would be needed to prevent the negative voltage in cells from expelling $\mathrm{HCO}_{3}^{-}$from cells?}

\section{Define function}

To maintain a high ICF $\mathrm{HCO}_{3}^{-}$concentration $\left(I_{\mathrm{HCO}_{3}}\right)$, a negative voltage should not cause $\mathrm{HCO}_{3}^{-}$to be exported or $\mathrm{H}^{+}$to be imported across cell membranes.

\section{Deduce controls}

$\mathrm{HCO}_{3}^{-}$and $\mathrm{H}^{+}$will not be driven across cells by a negative voltage if there are no ion channels for $\mathrm{HCO}_{3}^{-}$or $\mathrm{H}^{+}$in their membranes. This implies that the concentration of $\mathrm{H}^{+}$inside and outside cells will be regulated independently.

Because some organs produce and others use organic acids, $\mathrm{H}^{+}$and (or) $\mathrm{HCO}_{3}^{-}$must cross cell membranes electroneutrally. There are three electroneutral $\mathrm{H}^{+}$or $\mathrm{HCO}_{3}^{-}$ion transport systems. First, there are cotransporters for $\mathrm{H}^{+}$and the major biological monocarboxylate anions (L-lactate and ketoacid anions (Juel and Halestrap 1999)). Second, an equal number of $\mathrm{Na}^{+}$and $\mathrm{H}^{+}$could move in opposite directions (an electroneutral $\mathrm{Na}^{+} / \mathrm{H}^{+}$exchanger (NHE) (Solemani and Burham 2000)). Third, an equal number of $\mathrm{Cl}^{-}$and $\mathrm{HCO}_{3}^{-}$ could move in opposite directions (an electroneutral $\mathrm{Cl}^{-} / \mathrm{HCO}_{3}^{-}$ anion exchanger (AE) (Alper 1991)). Following their stoichiometries a little further, NHE must normally be an inactive state because the product of the concentrations of its substrates (ECF $\mathrm{Na}^{+}$and ICF $\mathrm{H}^{+}$) is more than an order of magnitude higher than the product of the concentrations of ICF $\mathrm{Na}^{+}$and ECF $\mathrm{H}^{+}$in steady state. When the NHE is activated, $\mathrm{Na}^{+}$enters cells down a concentration difference and $\mathrm{H}^{+}$exits for a similar reason (Fig. 8). On the one hand, this will alkalinize the cell; NHE flux cannot cause $\mathrm{H}^{+}$entry into normal cells. On the other hand, subsequent export of these intracellular $\mathrm{Na}^{+}$will occur by the $\mathrm{Na}^{+} / \mathrm{K}^{-}$ATPase that causes the interior of cells to become more electronegative (Moore 1983). Therefore, it is not surprising that the activator of NHE is insulin (Moore 1983), the signal of food $\left(+\mathrm{K}^{+}\right)$ intake, so that much of this ingested $\mathrm{K}^{+}$can be translocated into the ICF compartment to avoid a higher plasma $\mathrm{K}^{+}$concentration $\left(P_{\mathrm{K}}\right)$.

Again, because of steady-state $\mathrm{Cl}^{-}$and $\mathrm{HCO}_{3}^{-}$concentrations in the ECF and ICF compartments, we know that the $\mathrm{AE}$ is also in an inactive state in cell membranes. When this AE becomes active, $I_{\mathrm{HCO} 3}$ exits from cells because of the large transmembrane $\mathrm{Cl}^{-}$concentration difference (greater than an order of magnitude higher in the ECF compartment). 
Fig. 8. Effect of the transport of $\mathrm{H}^{+}$or $\mathrm{HCO}_{3}^{-}$on the resting membrane potential. The circle represents the cell membrane. Both $\mathrm{NHE}$ (left) and $\mathrm{AE}$ (right) are inactive at rest as evidenced by the concentration differences for the substrates and products of these electroneutral transporters (small shaded circles). After NHE is activated, $\mathrm{Na}^{+}$will be exported via $\mathrm{Na}^{+} / \mathrm{K}^{-} \mathrm{ATPase}$. This electrogenic export of $\mathrm{Na}^{+}$makes the interior voltage more negative. In contrast, after $\mathrm{AE}$ is activated, $\mathrm{Cl}^{-}$accumulates in cells. This leads to the electrogenic export of $\mathrm{Cl}^{-}$through its ion channel making the inside of cells less negative.
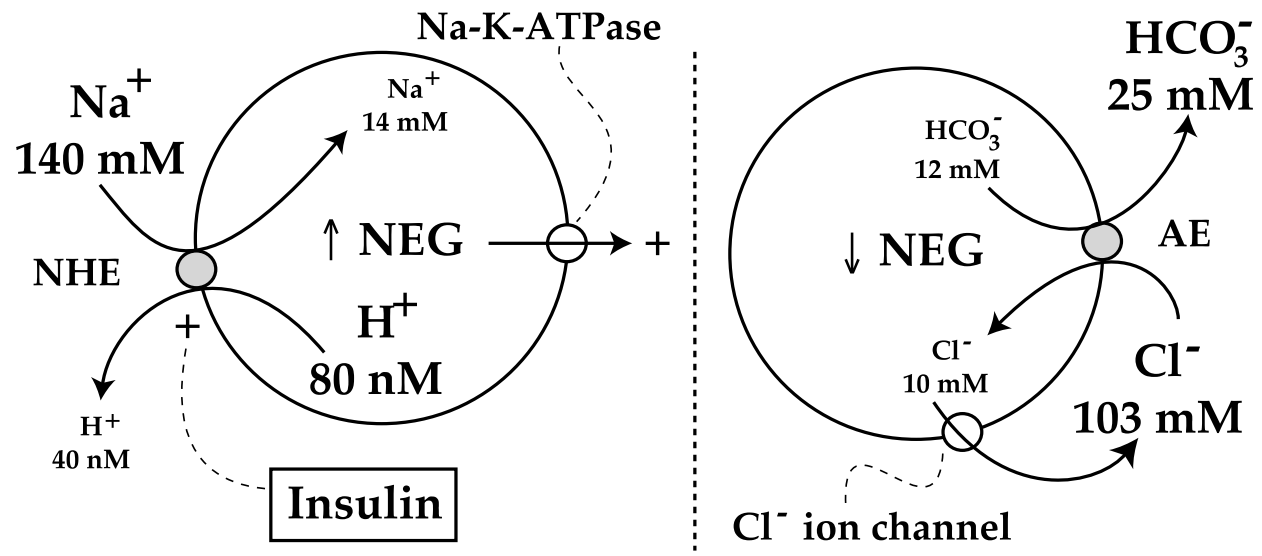

Looking at overall stoichiometry, because flux through the $\mathrm{AE}$ raises the concentration of $\mathrm{Cl}^{-}$in the ICF compartment, $\mathrm{Cl}^{-}$is driven out of cells by the negative intracellular voltage because there are $\mathrm{Cl}^{-}$channels in cell membranes (Jentsch 2000); this leads to a less negative ICF voltage, and secondary to this voltage change, $\mathrm{K}^{+}$exits from cells (DeMars et al. 2001). Hence, by selecting either NHE or the AE to influence the ICF $\mathrm{HCO}_{3}^{-}$or $\mathrm{H}^{+}$concentration, the resting membrane potential and $\mathrm{K}^{+}$movement will change in opposite directions.

\section{(c) Avoiding precipitation of $\mathrm{Ca}_{3}\left(\mathrm{PO}_{4}\right)_{2}$ in cells}

Question 16: What is the consequence of raising the concentration of $\mathrm{HPO}_{4}^{2-}$ in the ICF compartment during intense exercise?

\section{Define function}

When a sprint is initiated, ATP is hydrolyzed, yielding $\mathrm{ADP}$ (eq. 8a). In response to this rise in ADP, phosphocreatine is hydrolyzed and this leads to high levels of $\mathrm{HPO}_{4}^{2-}$ and an alkali load in cells (eq. 8). This rise in $\mathrm{HPO}_{4}^{2-}$ is very large in skeletal muscle cells because they have a large amount of phosphocreatine ( $25 \mathrm{mmol} / \mathrm{L} \mathrm{ICF})$. Overall, the $\mathrm{HCO}_{3}^{-}$load from the complete hydrolysis of phosphocreatine in skeletal muscle $(25 \mathrm{mmol} / \mathrm{L} \times 20 \mathrm{~L}=$ $\sim 500 \mathrm{mmol}$ ) is greater than the total ECF content of $\mathrm{HCO}_{3}^{-}$.

$$
\begin{aligned}
\mathrm{ATP}^{4-} \rightarrow \mathrm{ADP}^{3-} & +\mathrm{HPO}_{4}^{1.5-}+0.5 \mathrm{H}^{+} \\
\text {Phosphocreatine }^{3-} & +\mathrm{ADP}^{3-}+2 \mathrm{CO}_{2}+2 \mathrm{H}_{2} \mathrm{O} \\
& \rightarrow \mathrm{ATP}^{4-}+\text { creatine }^{0}+2 \mathrm{HCO}_{3}^{-}
\end{aligned}
$$

$$
\begin{aligned}
\text { Sum: phosphocreatine } & 3-+2 \mathrm{CO}_{2}+2 \mathrm{H}_{2} \mathrm{O} \\
& \rightarrow \mathrm{HPO}_{4}^{1.5-}+\text { creatine }^{0}+1.5 \mathrm{HCO}_{3}^{-} \\
\mathrm{H}^{+}+\mathrm{HPO}_{4}^{2-} & \leftrightarrow \mathrm{H}_{2} \mathrm{PO}_{4}^{-}
\end{aligned}
$$

Events differ a few seconds later in the sprint; ATP is formed predominantly by anaerobic glycolysis leading to high rates of L-lactic acid production (Cheetham et al. 1986). In this setting, the ICF $\mathrm{H}^{+}$concentration may rise by two to threefold, shifting eq. 9 to the right, converting $\mathrm{HPO}_{4}^{2-}$ to its monovalent form $\left(\mathrm{H}_{2} \mathrm{PO}_{4}^{-}\right)$that does not react with $I_{\mathrm{Ca}^{2+}}$. This $\mathrm{H}^{+}$concentration rise is particularly important because the $\mathrm{p} K$ for eq. 9 is only somewhat lower than the $\mathrm{pH}$ of the ICF compartment (Schwartz et al. 1959). It is the $\mathrm{HPO}_{4}^{2-}$ that is critical for the formation of the $\mathrm{Ca}_{3}\left(\mathrm{PO}_{4}\right)_{2}$ precipitate (Parks et al. 1997).

\section{Deduce controls}

Three facts can be deduced. First, cell membranes will restrict the movement of inorganic phosphate to avoid causing a rise in the $\mathrm{Ca}^{2+} \times \mathrm{HPO}_{4}^{2-}$ ion product in the ECF compartment. Second, the $I_{\mathrm{Ca}^{2+}}$ must always be low enough in cells to avoid unwanted precipitation reactions. Third, when intense exercise stops, phosphocreatinine is synthesized rapidly, yielding a very large $\mathrm{H}^{+}$load. This must occur when the muscle $P_{\mathrm{CO}_{2}}$ can fall to have the $\mathrm{H}^{+}$buffered primarily by its BBS.

\section{(d) Importance of the ICF $\mathrm{Ca}^{2+}$ concentration for metabolic regulation}

The $I_{\mathrm{Ca}^{2+}}$ is an important component of ICF regulatory systems. Based on an estimate of the highest $\mathrm{HPO}_{4}^{2-}$ concentration in skeletal muscle $\left(\mathrm{a} \mathrm{HPO}_{4}^{2-}\right.$ concentration greater than one order of magnitude higher than its concentration in the ECF compartment), one could avoid $\mathrm{Ca}_{3}\left(\mathrm{PO}_{4}\right)_{2}$ precipitation if the $I_{\mathrm{Ca}^{2+}}$ were always two orders of magnitude lower than its concentration in the ECF compartment $(\sim 1000 \mu \mathrm{M})$. In fact, the $I_{\mathrm{Ca}^{2+}}$ is $0.1 \mu \mathrm{M}$ at rest and it reaches a peak value of $10 \mu \mathrm{M}$, fulfilling this prophecy (Alberts et al. 1989). The requirement for having a $\mathrm{Ca}^{2+}$ signal system with an optimal range of $I_{\mathrm{Ca}^{2+}}$ will be examined in the discussion of question 17.

Question 17: In thermodynamic terms, how many fold must the $\mathrm{I}_{\mathrm{Ca}^{2}}$ rise so that after binding to its receptor on a regulatory signal protein, there will be enough energy to induce the desired protein conformational change?

\section{Define function}

At equilibrium with no ligand present, almost $100 \%$ of the regulatory signal protein must be in its inactive (or "off") form. 


\section{Deduce controls}

The following thermodynamic analysis illustrates how a regulatory protein may use changes in the $I_{\mathrm{Ca}^{2+}}$ as its signal switch mechanism. Four factors need to be considered to explain the energy requirements for $I_{\mathrm{Ca}^{2+}}$ to elicit a signal that is strong enough to switch an ICF regulatory protein from its "off" to an "on" configuration.

(i) Energy difference needed between two protein conformations to ensure that only a tiny proportion will be in the active form in the absence of a rise in the $\mathrm{I}_{\mathrm{Ca}^{2+}}$ - For a regulatory signal to be elicited only when there is a rise in the $I_{\mathrm{Ca}^{2+}}$, virtually $100 \%$ of that regulatory protein must exist in its "off" conformation at rest. The needed quantitative information concerning the energy difference between these two conformations can be obtained from the Boltzmann formula (eq. 10) where $\Delta G$ represents this energy difference between the two conformations of a regulatory protein (Tinoco et al. $1985)$. Close to $1420 \mathrm{cal} / \mathrm{mol}(1 \mathrm{cal}=4.184 \mathrm{~J})$ is needed to have a 10 -fold preference in distribution between its stable ("off") and high-energy ("on") configurations at body temperature, i.e., $10 \%$ of its molecules will be in the "on" position without binding of $I_{\mathrm{Ca}^{2+}}$. Because too much of this protein is still in the "on" conformation in the absence of $\mathrm{Ca}^{2+}$ binding, the energy difference between the stable and the high-energy states should be even higher to make this signal switch biologically useful. If this energy difference were $2840 \mathrm{cal} / \mathrm{mol}, 1 \%$ of the switch molecules would be in the "on" position in the absence of ligand binding. This is still not good enough for most cell signaling purposes, which require that the switch be designed to be "off" at the $99.9 \%$ level with a need for an energy difference of close to 4260 cal.

\section{[10]}

$$
\Delta G=-R T \ln X
$$

where $X=\left[\mathrm{Ca}^{2+}\right]_{\mathrm{ICF}}$ /affinity for $\left.\mathrm{Ca}^{2+}\right)$.

(ii) How much energy is available when $\mathrm{Ca}^{2+}$ binds to our regulatory protein? - The $I_{\mathrm{Ca}^{2+}}$ in the unstimulated state is $0.1 \mu \mathrm{M}$ (Alberts et al. 1989). Probably this nadir of $0.1 \mu \mathrm{M}$ was selected because a significantly lower $I_{\mathrm{Ca}^{2+}}$ in the basal state would slow binding of $\mathrm{Ca}^{2+}$ due to kinetic problems. When the $I_{\mathrm{Ca}^{2+}}$ is $0.1 \mu \mathrm{M}$ and $\mathrm{Ca}^{2+}$ binds to our signal protein, there are zero calories per mole of energy (i.e., $-R T \ln 1$ is zero). At $1 \mu \mathrm{M} I_{\mathrm{Ca}^{2+}}$, binding of $\mathrm{Ca}^{2+}$ to our signal protein would generate $1420 \mathrm{cal} / \mathrm{mol}$, which is not enough energy to turn the switch "on" if we must overcome the close to 4260 $\mathrm{cal} / \mathrm{mol}$ energy barrier. The calculation illustrates the thermodynamic argument why the basal $I_{\mathrm{Ca}^{2+}}$ must be quite low so that the $I_{\mathrm{Ca}^{2+}}$ can rise by much greater than 100-fold to have a signal system with less than $1 \%$ erroneous signal.

(iii) Range of $\mathrm{I}_{\mathrm{Ca}^{2+}}$ that would provide an optimal signal system - A 1\% random "on" position of our signal switch is probably too high for biological specificity. Therefore, another $1420 \mathrm{cal} / \mathrm{mol}$ would be needed for a mechanism with only a 0.1 erroneous "on" signal, bringing the energy difference to $4260 \mathrm{cal} / \mathrm{mol}$. This means that a 1000 -fold rise in the $I_{\mathrm{Ca}^{2+}}$ would be needed for full turn-"on", which is rather too much because it brings the $I_{\mathrm{Ca}^{2+}}$ to a range where there may be a $\mathrm{Ca}_{3}\left(\mathrm{PO}_{4}\right)_{2}$ problem in skeletal muscle early during a sprint.
In fact, the rise in the $I_{\mathrm{Ca}^{2+}}$ concentration should be closer to 100 - than 1000 -fold when $\mathrm{Ca}^{2+}$ signals are induced how can this dilemma of kinetics versus solubility be resolved? One answer might be to use two switches in series. Now if both are 99\% "off", the two in tandem are $99.99 \%$ "off" and that would make a good switch. In addition, these two switches must function independently and cannot be just two proteins in a cascade arrangement where, once one is signaled "on", this leads to both proteins being turned "on". A possible solution is to have the signal switches in a dimer conformation and require that $\mathrm{Ca}^{2+}$ bind to both to initiate activity. Thus, if thermodynamics were the only consideration, one could predict that the ICF receptor or signal switch will be a dimeric protein with no interaction between its units. $\mathrm{Ca}^{2+}$ must bind to each unit independently while they turn "on" separately. In this way, a 100-fold rise in $I_{\mathrm{Ca}^{2+}}$ would suffice to turn the switch "on" with only a $0.01 \%$ erroneous signal without ligand binding. In fact, calmodulin has two separate binding domains for $\mathrm{Ca}^{2+}$ on each half of this protein (Alberts et al. 1989) (see Appendix B). Of interest, two of the four binding sites for $\mathrm{Ca}^{2+}$ have a much lower affinity for $\mathrm{Ca}^{2+}$ (Alberts et al. 1989). The importance of these sites with a lower affinity for $\mathrm{Ca}^{2+}$ is considered in the following paragraph.

(iv) Prevent too large a rise in the $\mathrm{I}_{\mathrm{Ca}^{2+}}$ concentration - If the process that permits the $I_{\mathrm{Ca}^{2+}}$ to rise is activation of a $\mathrm{Ca}^{2+}$ channel, there needs to be a set of signals that decrease this channel activity and stimulate the $\mathrm{Ca}^{2+}$ removal mechanism when the $I_{\mathrm{Ca}^{2+}}$ rises more than 100-fold. Perhaps this might also explain the requirement for two types of binding sites for $\mathrm{Ca}^{2+}$ on calmodulin with a high affinity and two others with a lower affinity. These lower affinity sites should inhibit the $\mathrm{Ca}^{2+}$ channel activity (Alberts et al. 1989). In addition, as the $I_{\mathrm{Ca}^{2+}}$ rises, the $\mathrm{K}_{\mathrm{Ca}}$ channels become active (Fig. 5). When $\mathrm{K}^{+}$exits from cells, the ICF voltage becomes more negative and this closes the voltage-gated $\mathrm{Ca}^{2+}$ channels in the plasma membrane. This is, in fact, consistent with the bell-shaped curve depicting the $\mathrm{Ca}^{2+}$ concentration and channel activity (Bezprozvanny et al. 1991). In addition, the higher $I_{\mathrm{Ca}^{2+}}$ will activate the $\mathrm{Ca}^{2+}$ ATPase in plasma membranes as well as in endoplasmic reticulum membranes as well as an $\mathrm{Na}^{+} / \mathrm{Ca}^{2+}$ exchanger with a relatively lower affinity for $\mathrm{Ca}^{2+}$. These systems limit the peak $I_{\mathrm{Ca}^{2+}}$ to avoid both precipitation of $\mathrm{Ca}_{3}\left(\mathrm{PO}_{4}\right)_{2}$ and uncoupling oxidative phosphorylation.

\section{Composition of the urine}

\section{Define function}

All of the water-soluble waste products and all of the ions and water ingested in excess of needs must be excreted in the urine without forming precipitates.

\section{Deduce controls}

Excreting urine with a composition that makes ions or organic materials that are sparingly soluble in water more soluble is an important physiological response. Key to this aim is to have independent regulation of the urine $\mathrm{pH}$ : select a value that is close to 6.0 to achieve this aim (Coe and Parks 2000) (Fig. 9). Excreting urine at this $\mathrm{pH}$ must not sacrifice acid-base balance. This in turn means that with a large, 
Fig. 9. Urine $\mathrm{pH}$ and kidney stones. The safest urine $\mathrm{pH}$ to avoid kidney stones is close to 6 . Below this value, uric acid stones are most likely to form. By driving $\mathrm{NH}_{4}{ }^{+}$excretion with a high $\mathrm{NH}_{3}$ rather than a high $\mathrm{H}^{+}$concentration, a considerable quantity of $\mathrm{H}^{+}$can be eliminated at a urine $\mathrm{pH}$ close to 6.0. By excreting organic anions rather than $\mathrm{HCO}_{3}^{-}$, a considerable quantity of $\mathrm{HCO}_{3}^{-}$can also be eliminated at a urine $\mathrm{pH}$ close to 6.0 (see Fig. 10).

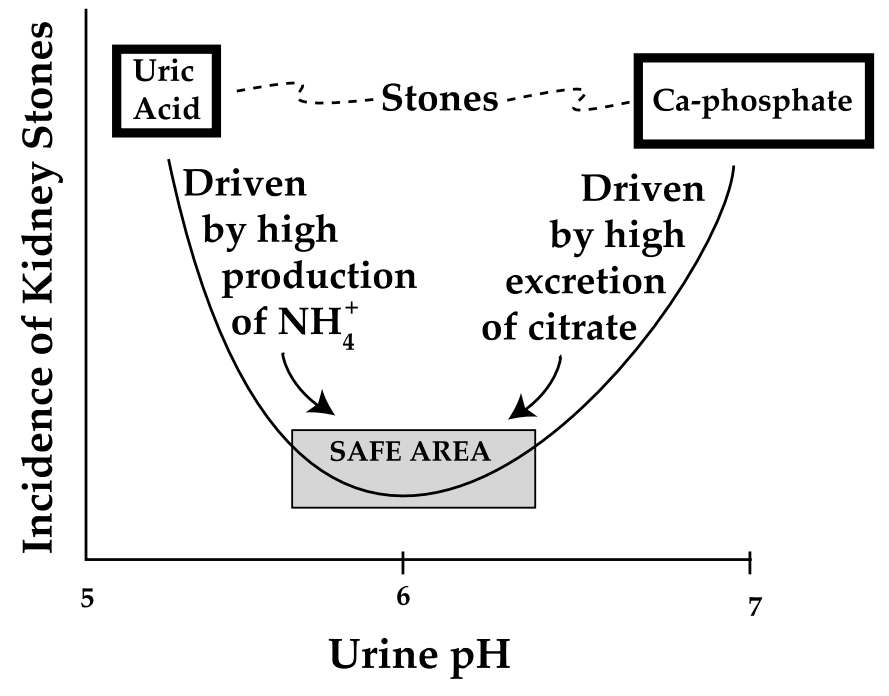

chronic acid load, the excretion of $\mathrm{NH}_{4}^{+}$should be maximally high at a urine $\mathrm{pH}$ of close to 6 (for further discussion, see Kamel et al. 1998). Similarly, when an alkali load is ingested, it must be excreted without obligating a large excretion of $\mathrm{HCO}_{3}^{-}$and thereby a high urine $\mathrm{pH}$ (Cheema-Dhadli et al. 2002; Lin et al. 1998); this latter topic will be discussed in more detail when $\mathrm{Ca}_{3}\left(\mathrm{PO}_{4}\right)_{2}$ stones are considered below.

\section{(a) Avoiding uric acid kidney stones}

Uric acid is the waste product of purine metabolism (Asplin 1996). The free acid form, uric acid, rather than total urates is the critical component for kidney stone formation because uric acid is sparingly soluble in water (eq. 11). Because the $\mathrm{pK}$ of uric acid in the urine at $37^{\circ} \mathrm{C}$ is close to 5.3 (Asplin 1996), precipitation of uric acid can be avoided without increasing the urine volume by raising the urine $\mathrm{pH}$ to 6 at the same total urate excretion rate (Kamel and Halperin 2002).

\section{[11] Urate $^{-}+\mathrm{H}^{+} \leftrightarrow$ uric acid ( $\mathrm{p} K$ 5.3)}

\section{(b) Avoiding $\mathrm{Ca}_{3}\left(\mathrm{PO}_{4}\right)_{2}$ kidney stones}

All of the $\mathrm{Ca}^{2+}$ absorbed from the GI tract of an adult is excreted in the urine in steady state (Bushinsky 1999). The chemistry of $\mathrm{Ca}^{2+}$ and $\mathrm{HPO}_{4}^{2-}$ in the urine is the same as in the body (Parks et al. 1997), but with one exception. A "metabolic equivalent" of $\mathrm{HCO}_{3}^{-}$, called citrate (Simpson 1983), can chelate $\mathrm{Ca}^{2+}$ in the urine, forming a soluble ion complex and thereby minimize the risk of $\mathrm{Ca}_{3}\left(\mathrm{PO}_{4}\right)_{2}$ kidney stone formation. This excretion of citrate rises with an alkali load (Simpson 1983), a time when urine $\mathrm{H}_{2} \mathrm{PO}_{4}^{-}$is converted to $\mathrm{HPO}_{4}^{2-}$, i.e., when the urine $\mathrm{pH}$ rises towards the $\mathrm{p} K$ of the phosphate buffer system ( $\mathrm{pH}$ 6.8). In more detail,
Fig. 10. Elimination of alkali of dietary origin. As a result of consuming fruits and vegetables, there is an alkali load $\left(\mathrm{K}^{+}+\right.$ $\mathrm{HCO}_{3}^{-}$, step 1). $\mathrm{HCO}_{3}^{-}$is removed by reacting with $\mathrm{H}^{+}$formed when organic acids including citric acid are produced during the metabolism of neutral precursors (step 2). Citrate anions are made into end-products of metabolism by being excreted in the urine because the $\mathrm{HCO}_{3}^{-}$load inhibits the renal reabsorption of citrate (site 3 ).

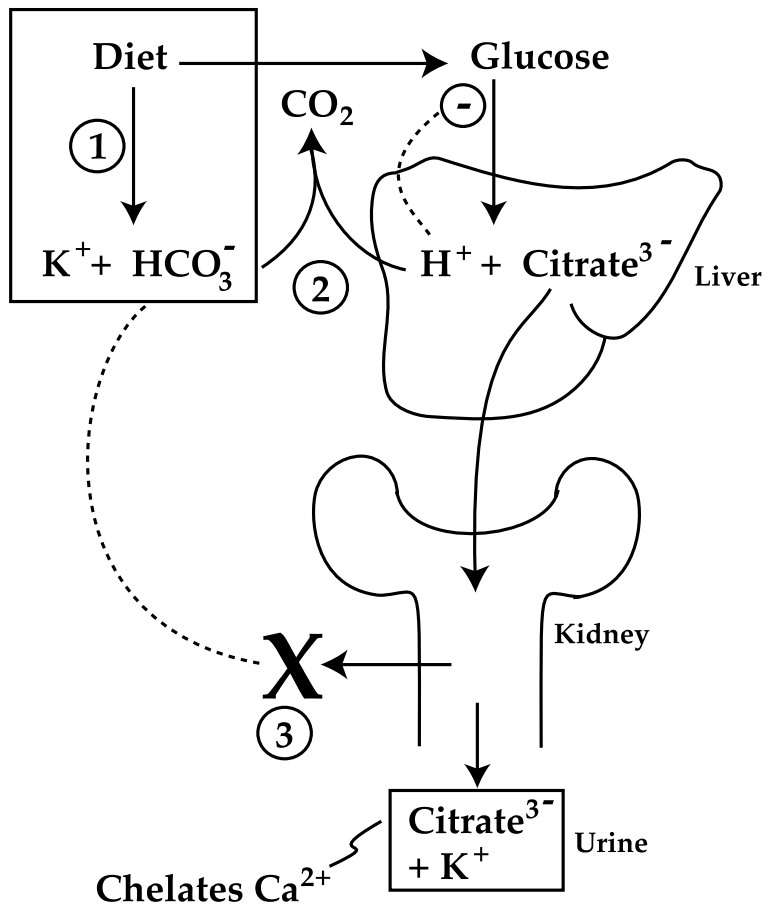

the body disposes of the usual alkali load of the diet by forming an organic acid such as citric acid (Cheema-Dhadli et al. 2002; Lin et al. 1998). The $\mathrm{H}^{+}$of citric acid is used to titrate $\mathrm{HCO}_{3}^{-}$. The citrate anions rather than an appreciable amount of $\mathrm{HCO}_{3}^{-}$are excreted in the urine so that the urine $\mathrm{pH}$ remains close to 6.0 without sacrificing acid-base balance (Kamel and Halperin 2002) (Figs. 9 and 10). Excreting citrate rather than $\mathrm{HCO}_{3}^{-}$when there is a dietary alkali load chelates $\mathrm{Ca}^{2+}$ in the urine, lessening the risk of $\mathrm{Ca}$ containing kidney stones in alkaline urine (Coe and Parks 1980).

\section{Integrative physiology of vigorous exercise}

We shall now utilize the concepts developed in earlier sections to describe the integrative physiology of vigorous exercise. This topic will be divided into two parts; the first focuses on alkalinization of the ICF compartment and the second deals with direct and indirect effects of this alkalinization.

\section{(a) Alkalinization of the ICF compartment of skeletal muscle}

There are two processes that cause the ICF $\mathrm{pH}$ to rise, a fall in $P_{\mathrm{CO}_{2}}$ (respiratory alkalosis) and a rise in $I_{\mathrm{HCO}_{3}}$ (metabolic alkalosis). The resultant fall in the ICF $\mathrm{H}^{+}$concentration causes proteins to become less cationic (or more 
Fig. 11. Integrative physiology of vigorous exercise (see text for details). The oval represents a muscle cell. The respiratory and metabolic processes that alkalinize its ICF compartment are shown in the left portion of the figure. The effects of that alkalinization are shown in the middle portion of the figure whereas the indirect response to the alkaline cell $\mathrm{pH}$, a less negative voltage of the ICF compartment (exit of $\mathrm{K}^{+}$from cells), is shown in the right portion of the figure.

$\begin{array}{lll}\text { ALKALINIZE } & \text { EFFECT } & \mathrm{pH}\end{array}$

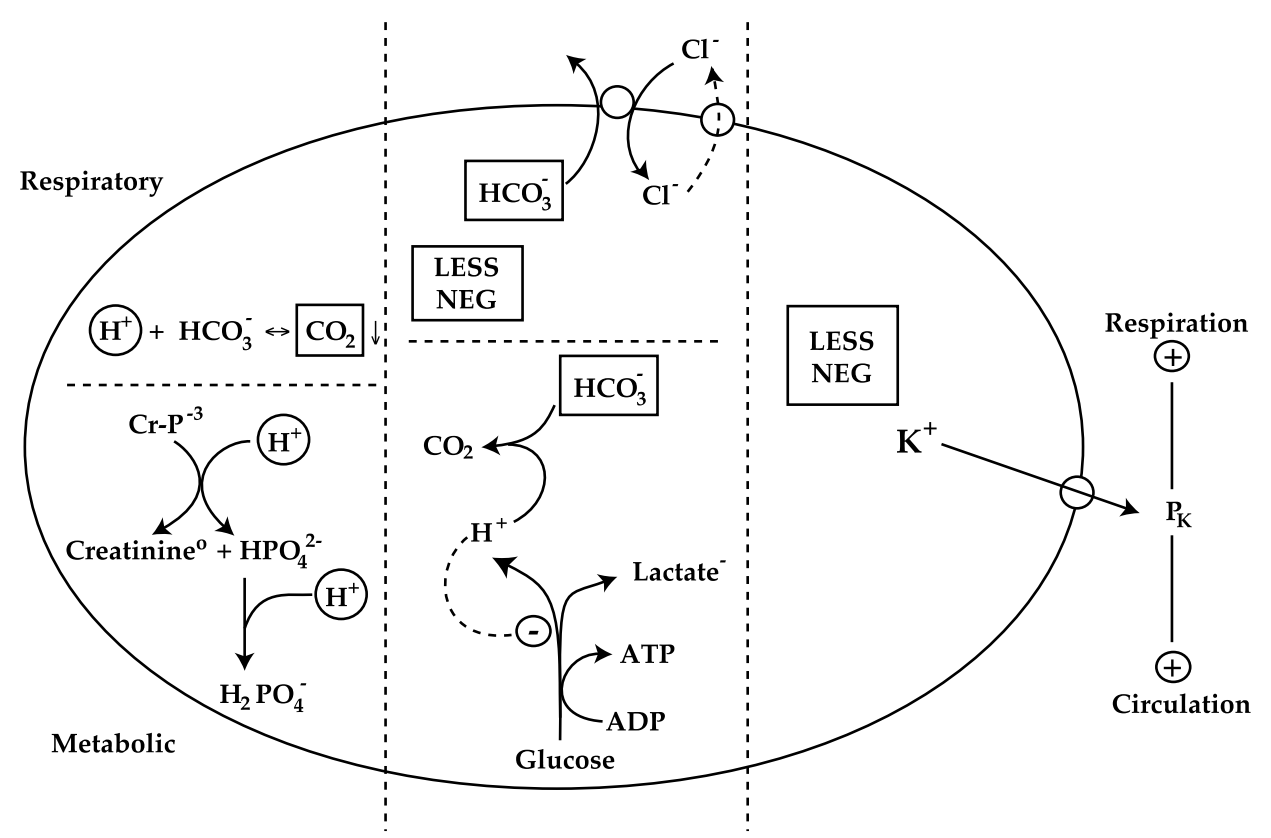

anionic) because they release some of their bound $\mathrm{H}^{+}$in response to the rise in ICF pH (Fig. 6; eq. 4) (Halperin and Goldstein 1998). This, in effect, permits a person to have the beneficial effects of the BBS before the sprint because $\mathrm{H}^{+}$ and $\mathrm{CO}_{2}$ will be produced in large quantities in this burst of exercise. By reducing the quantity of $\mathrm{H}^{+}$bound to proteins in skeletal muscle before the intense exercise occurs, there are more potential binding sites for $\mathrm{H}^{+}$on ICF proteins that are now in a more anionic form (Fig. 11). In contrast, after a second or two of intense exercise, $\mathrm{CO}_{2}$ production will rise enormously due to L-lactic acid generation $\left(\mathrm{H}^{+}\right.$reacts with $I_{\mathrm{HCO}_{3}}$ ) causing a rise in the tissue $P_{\mathrm{CO}_{2}}$. Hence, beginning the race with a tissue $P_{\mathrm{CO}_{2}}$ that is distinctly less than $40 \mathrm{mmHg}$ better defends protein structure.

(i) Respiratory alkalosis - The low arterial $P_{\mathrm{CO}_{2}}$ is due to a high adrenergic activity that leads to stimulation of alveolar ventilation. In the first second or two before the metabolic acidosis, release of $\mathrm{K}^{+}$from muscle cells seems to provide an additional stimulus to ventilation (see below).

(ii) Metabolic alkalosis - The anionic valence on phosphocreatine $^{3-}$ reflects the fact that its phosphate is a relatively strong acid (pK 2.7 and 4.6 (Dawson et al. 1969)) and it has a carboxyl group (Fig. 11). The initiation of work leads to a transient fall in ATP and rise in ADP. Because phosphocreatine plus ADP are converted to ATP and creatine ${ }^{0}$ by a near-equilibrium reaction, phosphocreatine is hydrolyzed promptly in response to a small rise in ADP, yielding less anionic products (eq. 8). For electroneutrality, $\mathrm{HCO}_{3}^{-}$is formed when $\mathrm{H}^{+}$is generated to create the cationic $\mathrm{NH}_{3}^{+}$group on creatine ${ }^{0}$ (eq. $8 b$ ). At the ambient cell $\mathrm{pH}$, most of the $\mathrm{HPO}_{4}^{2-}$ will be converted to $\mathrm{H}_{2} \mathrm{PO}_{4}^{-}$(eq. 9), requiring the generation of more $\mathrm{HCO}_{3}^{-}$via eq. 2 .

\section{(b) Effect of alkalinization of this ICF compartment}

There are three major effects of alkalinization of the ICF compartment. The two more direct ones are, first, a rise in the ICF $\mathrm{pH}$ to stimulate anaerobic glycolysis at PFK-1 (Halperin et al. 1969), and, second, to have a less negative transmembrane voltage. The indirect effect is to release $\mathrm{K}^{+}$ from cells to stimulate ventilation.

(i) Stimulation of anaerobic glycolysis - Alkalinization of the ICF compartment, when accompanied by a rise in adenosinemonophosphate (AMP) levels, could provide the initial signal to stimulate glycolysis by activating PFK-1 (Halperin et al. 1969). If this did not occur, a much larger fall in ATP and rise in AMP would be needed to activate PFK-1.

(ii) Export of alkali from cells - There is a net release of alkali from cells early in a sprint because the $\mathrm{pH}$ and $P_{\mathrm{HCO}_{3}}$ both rise in venous blood draining exercising muscles in the first 3 s of intense exercise (Wasserman et al. 1997). Because $\mathrm{HCO}_{3}^{-}$and (or) $\mathrm{H}^{+}$must be exported from cells via electroneutral cotransporters (Fig. 8), either NHE or AE could be a component of this process. Nevertheless, NHE cannot be involved in this process because it causes the export and not the entry of $\mathrm{H}^{+}$into cells owing to the $\mathrm{Na}^{+}$concentration difference between the ECF and ICF compartments. Thus, this export of alkali likely occurs via the $\mathrm{AE}$ cotransporter. Activation of the electroneutral $\mathrm{AE}$ will cause $\mathrm{HCO}_{3}^{-}$exit along with a stoichiometric gain of 
$\mathrm{Cl}^{-}$in the ICF compartment. The resultant higher ICF $\mathrm{Cl}^{-}$ concentration obligates $\mathrm{Cl}^{-}$exit from cells via $\mathrm{Cl}^{-}$channels, lessening the net negative voltage in these cells (Fig. 8).

(iii) Release of $\mathrm{K}^{+}$from muscle cells - The indirect effect of alkalinization of the ICF compartment is a less negative resting membrane potential. As a result, $\mathrm{K}^{+}$will move from the ICF to the ECF compartment, leading to a rise in the $P_{\mathrm{K}}$ early in vigorous exercise. There are two important potential roles of this rise in $P_{\mathrm{K}}$. First, hyperkalemia will stimulate alveolar ventilation provided that the arterial $P_{\mathrm{CO}_{3}}$ does not fall (Patterson 1992). Therefore, alveolar ventilation can be augmented without requiring its usual stimulators, a low $P_{\mathrm{O}_{2}}$, metabolic acidosis, or a high arterial $P_{\mathrm{CO}_{2}}$. Alveolar ventilation could also be stimulated by nervous impulses from exercising muscles and this might be facilitated by a high $\mathrm{K}^{+}$concentration around these nerve endings. The net result is having an arterial $P_{\mathrm{CO}_{2}}$ distinctly less than $40 \mathrm{mmHg}$. Second, an elevated $P_{\mathrm{K}}$ can cause local vasodilation and thereby have a circulatory benefit during intense exercise.

\section{(c) Increase in blood flow}

Control of blood flow was discussed in Section II. The essential element is that local release of $\mathrm{L}^{-l a c t a t e}{ }^{-}$and $\mathrm{H}^{+}$ causes vasodilation because these ions lead to a more open configuration of the $\mathrm{K}_{\mathrm{ATP}}$ channels in vascular smooth muscle cells (Fig. 5). When $\mathrm{K}^{+}$diffuses out of cells, the ICF voltage becomes more negative, voltage-gated $\mathrm{Ca}^{2+}$ channels close, the $I_{\mathrm{Ca}^{2+}}$ falls, and as a result, there is less vasoconstriction.

\section{Concluding remarks}

Integrative physiology is a critically important subject for the clinician and student. Because it involves a series of interconnected events, it is a particularly difficult subject to examine. Thinking by subspecialty hinders a broad understanding in this area. An appreciation of basic sciences such as chemistry and physics helps provide answers to important questions, but interpretations will need to undergo modification with insights gained from molecular biology. By starting with a very important question concerning survival, the trail followed involved a quantitative analysis of work, energy, $\mathrm{O}_{2}, \mathrm{CO}_{2}, \mathrm{H}^{+}$, $\mathrm{HCO}_{3}^{-}$, carbonate, ionized calcium, inorganic phosphate, metabolic regulation by $\mathrm{Ca}^{2+}$, and avoiding kidney stones. The outcome permitted us to deduce the basis for the normal ionic composition and volume of our ECF and ICF compartments. All of these features were illustrated by considering the integrative physiology of vigorous exercise.

\section{References}

Alberts, B., Bray, D., Lewis, J., Raff, M., Roberts, K., and Watson, J.D. 1989. Molecular biology of the cell. 2nd ed. Garland Publishing, New York. pp. 304-317.

Alper, S. 1991. The band 3-related anion exchanger (AE) gene family. Annu. Rev. Physiol. 53: 549-564.

Asplin, J.R. 1996. Uric acid stones. Semin. Nephrol. 16: 412-424.

Beckman, K.B., and Ames, B.N. 1998. The free radical theory of ageing matures. Physiol. Rev. 78: 547-581.

Beveridge, W.I.B. 1951. Art of scientific thinking. Penguin Books, London, U.K.
Bezprozvanny, I., Watras, J., and Ehrilch, B.E. 1991. Bell-shaped calcium-response curves of $\operatorname{Ins}(1,4,5) \mathrm{P}_{3^{-}}$and calcium-gated channels from endoplasmic reticulum of cerebellum. Nature (Lond.), 351: 751-754.

Boss, O., Samec, S., Dulloo, A., Seydoux, J., Muzzin, P., and Giacobino, J.-P. 1997. Tissue-dependent upregulation of rat uncoupling protein 2-expression in response to fasting or cold. FEBS Lett. 412: 111-114.

Brand, M.D. 2000. Uncoupling to survive? The role of mitochondrial inefficiency in ageing. Exp. Gerontol. 35: 811-820.

Bushinsky, D.A. 1999. Calcium, magnesium, and phosphorus: renal handling and urinary excretion. In Primer on the metabolic bone diseases and disorders of mineral metabolism. Lippincott Williams \& Wilkins, Philadelphia, Pa. pp. 67-74.

Cheema-Dhadli, S., Lin, S.-H., and Halperin, M.L. 2002. Mechanisms used to dispose of a progressively increasing alkali load in the rat. Am. J. Physiol. 282: F1049-F1055.

Cheetham, M.E., Boobis, L.H., Brooks, S., and Williams, C. 1986. Human muscle metabolism during sprint running. J. Appl. Physiol. 61: 54-60.

Coe, F.L., and Parks, J.H. 1980. Stone disease in hereditary distal renal tubular acidosis. Ann. Intern. Med. 93: 60-61.

Coe, F.L., and Parks, J.H. 2000. Pathogenesis and treatment of nephrolithiasis. In The kidney: physiology and pathophysiology. Edited by D.W. Seldin and G. Giebisch. Lippincott Williams \& Wilkins, Philadelphia, Pa. pp. 1841-1867.

Cohen, R.D., and Woods, H.F. 1976. Type A lactic acidosis. In Clinical and biochemical aspects of lactic acidosis. Edited by R.D. Cohen and H.F. Woods. Blackwell Scientific Publications, Oxford, U.K. pp. 77-91.

Czech, M.P., Klarlund, J.K., Yagaloff, K.A., Bradford, A.P., and Lewis, R.E. 1988. Insulin receptor signalling: activation of multiple serine kinases. J. Biol. Chem. 263: 11017 - 11020.

Dawson, R.M.C., Elliott, D., Elliott, W.H., and Jones, K.M. 1969. Data for biochemical research. Oxford Univsity Press, London, U.K. pp. 106-107.

DeMars, C., Hollister, K., Tomassoni, A., Himmelfarb, J., and Halperin, M.L. 2001. Citric acidosis: a life-threatening cause of metabolic acidosis. Ann. Emerg. Med. 38: 588-591.

Denton, R.M., and Halestrap, A.P. 1979. Regulation of pyruvate metabolism in mammalian tissues. Essays Biochem. 15: 37-77.

Echtay, K.S., and Brand, M.D. 2001. Coenzyme Q induces GDPsensitive conductance in kidney mitochondria. Biochem. Soc. Trans. 29: 763-768.

Giebisch, G. 1998. Renal potassium transport: mechanisms and regulation. Am. J. Physiol. 274: F817-F833.

Goodale, W.T., Olson, R.E., and Hackel, D.B. 1959. The effects of fasting and diabetes mellitus on myocardial metabolism in man. Am. J. Med. 27: 212-220.

Halperin, M.L., and Goldstein, M.B. 1998. Fluid, electrolyte and acid-base physiology; a problem-based approach. W.B. Saunders, Philadelphia, Pa.

Halperin, M.L., and Jungas, R.L. 1983. Metabolic production and renal disposal of hydrogen ions. Kidney Int. 24: 709-713.

Halperin, M.L., and Rolleston, F.S. 1993. Clinical detective stories: a problem-based approach to clinical cases in energy and acidbase metabolism. Vol. 1. Portland Press, London, U.K. pp. 273-274.

Halperin, M.L., Connors, H.P., Relman, A.S., and Karnovsky, M.L. 1969. Factors that control the effect of $\mathrm{pH}$ on glycolysis in leukocytes. J. Biol. Chem. 244: 384.

Harper, M.-E., Dent, R.M., Bezaire, V., Antoniou, A., Gauthier, A., Monemdjou, S., and McPherson, R. 2001. UCP3 and its putative function: consistencies and controversies. Biochem. Soc. Trans. 29: $768-773$. 
Jentsch, T.J. 2000. Neuronal KCNQ channel: physiology and role in disease. Nat. Rev. Neurosci. 1: 21-30.

Juel, C., and Halestrap, A.P. 1999. Lactate transport in skeletal muscle - role and regulation of the monocarboxylate transporter. J. Physiol. 517: 633-642.

Kamel, K.S., and Halperin, M.L. 2002. Studies on the pathophysiology of the low urine $\mathrm{pH}$ in patients with uric acid stones. Kidney Int. 61: 988-994.

Kamel, K.S., Lin, S.-H., Cheema-Dhadli, S., Marliss, E.B., and Halperin, M.L. 1998. Prolonged total fasting: a feast for the integrative physiologist. Kidney Int. 53: 531-539.

Landry, D.W., and Oliver, J.A. 2001. The pathogenesis of vasodilatory shock. N. Engl. J. Med. 345: 588-595.

Lin, P., Cheema-Dhadli, S., Chayaraks, S., Chen, C.-B., Gowrishankar, M., and Halperin, M.L. 1998. Physiological role of the potential alkali load in the diet of the rat for acid-base balance. Am. J. Physiol. 274: F1037-F1044.

Lowell, B.B., and Spiegelman, B.M. 2000. Towards a molecular understanding of adaptive thermogenesis. Nature (Lond.), 404: 652-660.

Lutz, P.L. 1992. Mechanisms for anoxic survival in the vertebrate brain. Annu. Rev. Physiol. 54: 601-618.

Miller, C. 2000. An overview of the potassium channel family. Genome Biol. 1: 1-5.

Mitchell, P. 1961. Coupling of phosphorylation to electron and hydrogen transfer by a chemi-osmotic type of mechanism. Nature (Lond.), 191: 144-148.

Moore, R.D. 1983. Effects of insulin upon ion transport. Biochim. Biophys. Acta, 737: 1-49.

Nahas, G.G., Zaguy, D., and Milhard, A. 1967. Acidemia and catecholamine output of the isolated canine adrenal gland. Am. J. Physiol. 213: 1186-1192.

Owen, O.E., Morgan, A.P., Kemp, H.G., Sullivan, J.M., Herrera, M.G., and Cahill, G.F.J. 1967. Brain metabolism during fasting. J. Clin. Invest. 46: 1589-1595.

Parks, J.H., Coward, M., and Coe, F.L. 1997. Correspondence between stone composition and urine supersaturation in nephrolithiasis. Kidney Int. 51: 894-900.

Patterson, D.J. 1992. Potassium and ventilation in exercise. J. Appl. Physiol. 72: 811-820.

Quayle, J.M., Nelson, M.T., and Standen, N.B. 1997. ATPsensitive and inwardly rectifying potassium channels in smooth muscle. Physiol. Rev. 77: 1165-1232.

Randle, P.J. 1986. Fuel selection in animals. Biochem. Soc. Trans. 14: 799-806.

Rial, E., Poustie, A., and Nicholls, D.G. 1983. Brown-adiposetissue mitochondria: the regulation of the $32000-M_{\mathrm{r}}$ uncoupling protein by fatty acids and purine nucleotides. Eur. J. Biochem. 137: 197-203.

Russell, J.M. 2000. Sodium-potassium-chloride cotransport. Physiol. Rev. 80: 211-276.

Schmidt-Nielsen, K. 1997. Animal physiology: adaptation and environment. 5th ed. Cambridge University Press, Cambridge, U.K.

Schwartz, W.B., Bank, N., and Cutler, R.W.P. 1959. The influence of urinary ionic strength on phosphate $p \mathrm{~K}_{2}$ and the determination of titratable acid. J. Clin. Invest. 38: 347-356.

Simpson, D. 1983. Citrate excretion: a window on renal metabolism. Am. J. Physiol. 244: F223-F234.

Solemani, M., and Burham, C. 2000. Physiology and molecular aspects of the $\mathrm{Na}^{+}: \mathrm{HCO}_{3}^{-}$contransporter in health and disease processes. Kidney Int. 57: 371-384.

Taylor, B.S., and Geller, D.A. 2000. Molecular regulation of the human inducible nitric oxide synthase (iNOS) gene. Shock, 13: 413-424.
Tinoco, I., Jr., Sauer, K., and Wang, J.C. 1985. Physical chemistry: principles and application in biologic science. 2nd ed. Chap. 11. Prentice Hall, Englewood Cliffs, N.J.

Wasserman, K., Stringer, W.W., Casaburi, R., and Zhang, Y.-Y. 1997. Mechanism of the exercise hyperkalemia: an alternate hypothesis. J. Appl. Physiol. 83: 631-643.

Wollheim, C.B. 2000. Beta-cell mitochondria in the regulation of insulin secretion: a new culprit in type II diabetes. Diabetologia, 43: $265-277$.

\section{Appendix A. Concentration of $\mathrm{O}_{\mathbf{2}}$ in blood}

Each millimole of hemoglobin binds $4 \mathrm{mmol}$ of $\mathrm{O}_{2}$. Because the molecular mass of hemoglobin is close to 70000 and that each litre of blood has $140000 \mathrm{mg}$ of hemoglobin, there are $8 \mathrm{mmol}$ of $\mathrm{O}_{2}$ bound to hemoglobin per litre of blood.

\section{Appendix B. Importance of dimers}

Dimers might have broader biological implications. For example, hormone receptors often function when in a dimer conformation on the cell surface (Czech et al. 1988). This makes the need for circulating hormone concentrations to be 10 -fold lower while having a reliable switch mechanism. Hence, their renal clearance is not important at these low concentrations.

\section{Appendix $\mathrm{C} . \mathrm{H}^{+}$production and glycolysis}

With a deficit of $\mathrm{O}_{2}$, glucose must be broken down to L-lactate by anaerobic glycolysis to reconvert ADP to ATP. However, the proton released when ATP was broken down to ADP cannot be buffered by the L-lactate so it will accumulate. The complete equation for anaerobic glycolysis is

$$
\begin{aligned}
\text { Glucose }+2 \mathrm{P}_{\mathrm{i}}{ }^{2-}+2 \mathrm{ADP} \cdot \mathrm{Mg}^{-} & \rightarrow 2 \text { L-Lactate } \\
+ & 2 \mathrm{ATP} \cdot \mathrm{Mg}^{2-}+2 \mathrm{H}_{2} \mathrm{O}
\end{aligned}
$$

Note that there is no production of protons in this process, but glycolysis cannot occur unless work is first performed. This will cause the following:

$$
\begin{aligned}
2 \mathrm{H}_{2} \mathrm{O}+2 \text { ATP } \cdot \mathrm{Mg}^{2-} & \rightarrow \text { work } \\
& \rightarrow 2 \mathrm{ADP} \cdot \mathrm{Mg}^{-}+2 \mathrm{P}_{\mathrm{i}}{ }^{2-}+2 \mathrm{H}^{+}
\end{aligned}
$$

Thus when work and glycolysis both occur the result is the sum of the above two equations:

$$
\text { [C3] Glucose } \rightarrow \text { work/glycolysis } \rightarrow 2 \text { L-Lactate }^{-}+2 \mathrm{H}^{+}
$$

In other words, glycolysis cannot produce both ATP and $\mathrm{H}^{+}$; it can produce ATP (eq. C1) or it can produce $\mathrm{H}^{+}$(eq. C3) when coupled with work. It is the work that produces the $\mathrm{H}^{+}$. Note that we treated all changes as whole integers; they are really fractional, of course, but giving the exact changes does not alter the argument. 